\title{
Synthesis and Preliminary Anticancer Activity Assessment of N-Glycosides of 2-Amino-1,3,4-thiadiazoles
}

\author{
Katarzyna Żurawska ${ }^{1,2}{ }^{\mathbb{D}}$, Marcin Stokowy ${ }^{1}$, Patryk Kapica ${ }^{1,2}$, Monika Olesiejuk ${ }^{3} \mathbb{D}$, Agnieszka Kudelko ${ }^{3} \mathbb{D}$, \\ Katarzyna Papaj ${ }^{2}$, Magdalena Skonieczna 2,4 (D), Wiesław Szeja ${ }^{1}$, Krzysztof Walczak ${ }^{1}$ (D) \\ and Anna Kasprzycka $1,2, *$ (D)
}

1 Department of Organic Chemistry, Bioorganic Chemistry and Biotechnology, Faculty of Chemistry, Silesian University of Technology, Krzywoustego Street 4, 44-100 Gliwice, Poland; Katarzyna.Hopko@polsl.pl (K.Ż.); szoko1@gmail.com (M.S.); kapica.patrick@gmail.com (P.K.); wieslaw.szeja@adres.pl (W.S.); krzysztof.walczak@polsl.pl (K.W.)

2 Centre of Biotechnology, Silesian University of Technology, Krzywoustego Street 8, 44-100 Gliwice, Poland; katarzyna.papaj@polsl.pl (K.P.); Magdalena.Skonieczna@polsl.pl (M.S.)

3 Department of Chemical Organic Technology and Petrochemistry, The Silesian University of Technology, Krzywoustego Street 4, 44-100 Gliwice, Poland; monika.olesiejuk@polsl.pl (M.O.); Agnieszka.Kudelko@polsl.pl (A.K.)

4 Department of Systems Biology and Engineering, The Silesian University of Technology, Akademicka Street 16, 44-100 Gliwice, Poland

* Correspondence: anna.kasprzycka@polsl.pl

check for updates

Citation: Żurawska, K.; Stokowy, M.; Kapica, P.; Olesiejuk, M.; Kudelko, A.; Papaj, K.; Skonieczna, M.; Szeja, W.;

Walczak, K.; Kasprzycka, A. Synthesis and Preliminary Anticancer Activity Assessment of N-Glycosides of 2-Amino-1,3,4-thiadiazoles. Molecules 2021, 26, 7245. https://doi.org/ $10.3390 /$ molecules 26237245

Academic Editor: Francesca Cardona

Received: 7 November 2021

Accepted: 25 November 2021

Published: 29 November 2021

Publisher's Note: MDPI stays neutral with regard to jurisdictional claims in published maps and institutional affiliations.

Copyright: (c) 2021 by the authors. Licensee MDPI, Basel, Switzerland. This article is an open access article distributed under the terms and conditions of the Creative Commons Attribution (CC BY) license (https:/ / creativecommons.org/licenses/by/ $4.0 /)$.

\begin{abstract}
The addition of 2-amino-1,3,4-thiadiazole derivatives with parallel iodination of differently protected glycals has been achieved using a double molar excess of molecular iodine under mild conditions. The corresponding thiadiazole derivatives of N-glycosides were obtained in good yields and anomeric selectivity. The usage of iodine as a catalyst makes this method easy, inexpensive, and successfully useable in reactions with sugars. Thiadiazole derivatives were tested in a panel of three tumor cell lines, MCF-7, HCT116, and HeLa. These compounds initiated biological response in investigated tumor models in a different rate. The MCF-7 is resistant to the tested compounds, and the cytometry assay indicated low increase in cell numbers in the sub- G1 phase. The most sensitive are HCT-116 and HeLa cells. The thiadiazole derivatives have a pro-apoptotic effect on HCT-116 cells. In the case of the HeLa cells, an increase in the number of cells in the sub-G1- phase and the induction of apoptosis was observed.
\end{abstract}

Keywords: glycal; N-glycosides; molecular iodine; 1,3,4-thiadiazole

\section{Introduction}

1,3,4-Thiadiazole represents an important heterocyclic scaffold due to its pharmacological activity. Their derivatives exhibit various and significant activities such as antibacterial [1], antifungal, anti-inflammatory [2], anti-tuberculosis [3], antidepressant [4], and anticancer [5-7] activities, etc. The 1,3,4-Thiadiazole ring influences cancer cell lines mainly due to ability of nitrogen atoms to donate electrons and form hydrogen bonds or chelate certain metal ions [8]. The introduction of additional substituents (e.g., the $-\mathrm{NH}_{2}, \mathrm{SO}_{3} \mathrm{H}$ group, etc.) on the C-2 and/or C-5 carbon atoms of the thiadiazole ring enhances the desired properties. Moreover, the amino derivatives of 1,3,4-thiadiazole, which have different biocidal effects, are also investigated, probably due to the toxophore group N=C-S- [8-10]. As ligands, they also provide many potential binding sites for complexation and have diverse biological activity [11].

It is well known that derivatives of 1,3,4-thiadiazoles exhibit anti-tumor activity against human cancer cells (MCF-7 (breast cancer), SMMC-7721 (human hepatocarcinoma), HL-60 (human leukemia), A549 (non-small cell lung carcinoma), Hep-G2 (human liver hepatocellular carcinoma), PC-3 (human prostate adenocarcinoma), and HCT-116 (human 
colorectal carcinoma); Figure 1) [12-18]. The molecular targets belong to a group of proteins involved in proliferation, survival, and metastasis. These include carbonic anhydrase, matrix metalloproteinases, histone deacetylases, tubulin, focal adhesion kinases, protein tyrosine kinases, etc. $[8,9,19-28]$. The conjugation of drugs with sugar molecules in many cases improves their distribution into the cells. Several anticancer drugs such as glufosfamide, paclitaxel, and chlorambucil were conjugated with glucose for improving cancer targeting and selectivity [29].

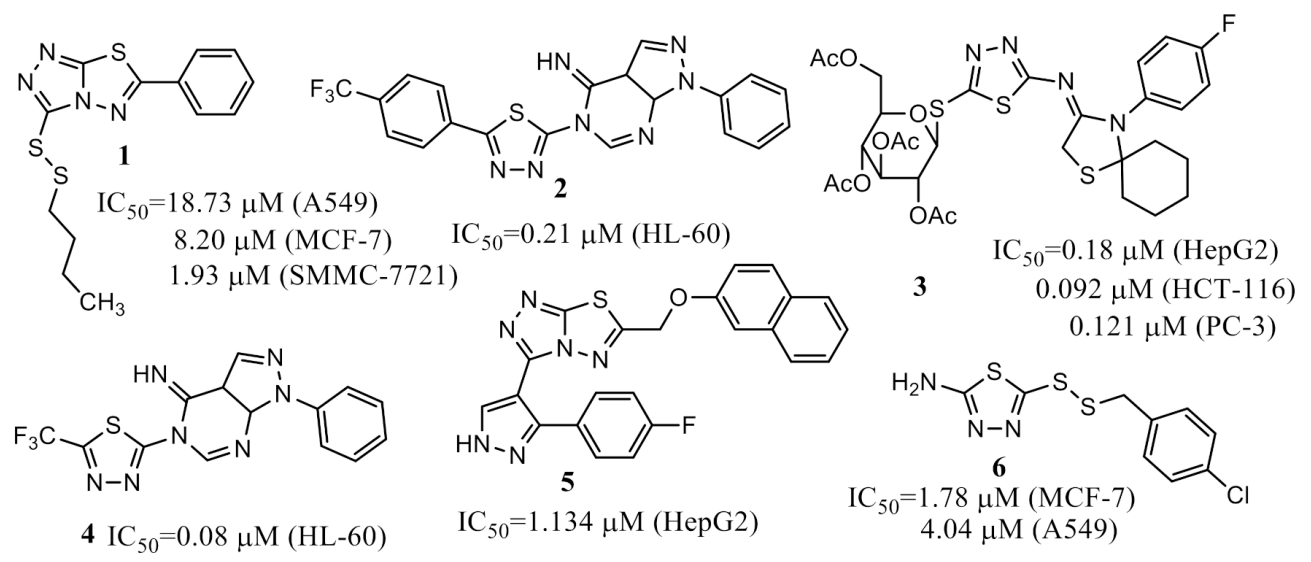

Figure 1. Anti-tumor active compounds with 1,3,4-thiadiazole core [12].

Priebe et al. [30] reported the synthesis of new iodo-hexose compounds and their preliminary antitumor application for the treatment of glioblastoma and pancreatic cancer, which showed better anti-tumor activity in contrast to their deoxy-analogs. On the other hand, glycals are versatile building blocks in carbohydrate synthetic chemistry and have been extensively investigated for the synthesis of 2-deoxy-O-, $\mathrm{S}-, \mathrm{N}$-glycosides. The method for entry into 2-deoxy glycosides has been discussed in several reviews [31-35].

Continuing this study, we present the synthesis and biological activity of conjugates possessing different 2-deoxy-2-iodomonosaccharide scaffolds joined with thiadiazole derivatives.

\section{Results and Discussion}

\subsection{Synthesis}

In the present work, the synthesis of aminoglycosides in the reaction of glycals with 2-amino-1,3,4-thiadiazole derivatives has been studied. The preliminary antitumor activity of obtained conjugates was determined. The targeted conjugates were obtained by the addition of the 2-amino-1,3,4-thiadiazole derivative (2) to an unsaturated sugar (1) in the presence of iodine (Scheme 1).<smiles>[R]c1ccc(-c2nnc(N[C@@H]3OCC(=O)C[C@H]3I)s2)cc1</smiles>

$\mathbf{R}=\mathrm{tBu}, \mathrm{H}, \mathrm{F}, \mathrm{Cl}$

Scheme 1. Synthesis of glycoconjugates, derivatives of 1,2,4-thiadiazole.

The glycosylation of the glycal derivatives was performed in the dark at room temperature. The main products formed by the addition of iodine (Scheme 1) to the double bond of 3,4-di-O-acetyl-L-rhamnal (1a), 3,4-di-O-benzyl-L-rhamnal (1d), 3,4,6-tri-O-acetylD-glucal (1b), and 3,4,6-tri-O-acetyl-D-galactal (1c), followed by a substitution reaction, were isolated by column chromatography. The structures of the obtained compounds were established based on the analysis of their NMR spectra. The signals were identified using literature data [36,37]. Additionally, in the ${ }^{1} \mathrm{H}$ NMR spectra, the following were diagnostic: 
chemical shifts of acetyl groups, hydrogen at the anomeric position, hydrogens at C-6 position for rhamnopyranose derivatives, and hydrogen at $\mathrm{C}-2$. In the ${ }^{13} \mathrm{C}$ NMR spectrum were the $\mathrm{C}-1, \mathrm{C}-2$, and $\mathrm{S}-\mathrm{C}=\mathrm{N}$ carbon chemical shifts.

To determine the reaction conditions, we performed preliminary experiments presented in: Table 1.

Table 1. Study on the reaction of 3,4-di-O-acetyl-L-rhamnal iodoamination(1a).

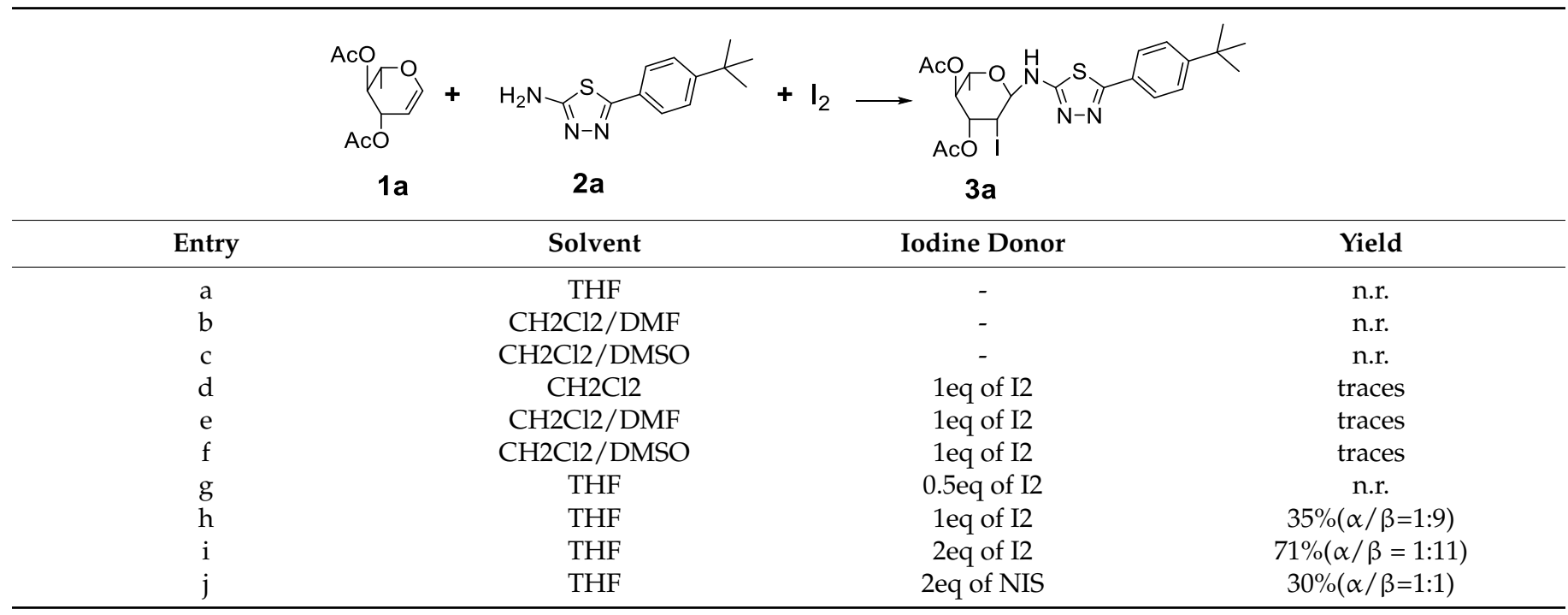

When the 3,4-di-O-acetyl-L-rhamnal (1a) was treated with 2-amino-5-(4-tert-butylphenyl)1,3,4-thiadiazole (2a) in different solvents (Entry a-c) and in the absence of iodine, no substrate conversion was observed. In the second set of experiments, the reaction was carried out in the presence of 1 eq. of iodine in the mixture of solvents with different polarities (Entry $\mathbf{d}-\mathbf{f})$. Under applied conditions, only traces of the product were detected. The third set of experiments was carried out in THF in the presence of a different concentration of iodine, namely, 0.5, 1.0, and 2.0 eq (Entry g-i). These results indicated that the reaction occurred successfully in the presence of double molar excess of molecular iodine. To determine which of the iodoamination methods would be the most beneficial, an experiment with NIS was also performed (Entry $\mathbf{j}$ ), this reactant is recommended as conventional in synthesis 2-deoxy-2-halogenosugars starting from glycals [36]. The presence of an additional product in a very high concentration prompted us to abandon this method. Other methods of addition using heavy metals as catalysts are also known [38]. Unfortunately, the residue of those metals in the tested sample could adversely affect the survival of cells and the results of biological tests, so we decided to give up these methods as well.

In a series of experiments, we carried out reactions of 3,4-di-O-acetyl-L-rhamnal (1a), 3,4,6-tri-O-acetyl-D-glucal (1b), 3,4,6-tri-O-acetyl-D-galactal (1c), and 3,4-di-O-benzylL-rhamnal (1d) with 2-amino-5-phenyl-1,3,4-thiadiazole derivatives (2a-2d) containing different substituents in the aromatic ring in anhydrous THF containing molecular iodine. As a result of these experiments, hitherto unknown derivatives $3 \mathbf{a}-3 \mathbf{m}$ were obtained. The results are presented in Table 2. 
Table 2. Iodoamination of selected glycals.

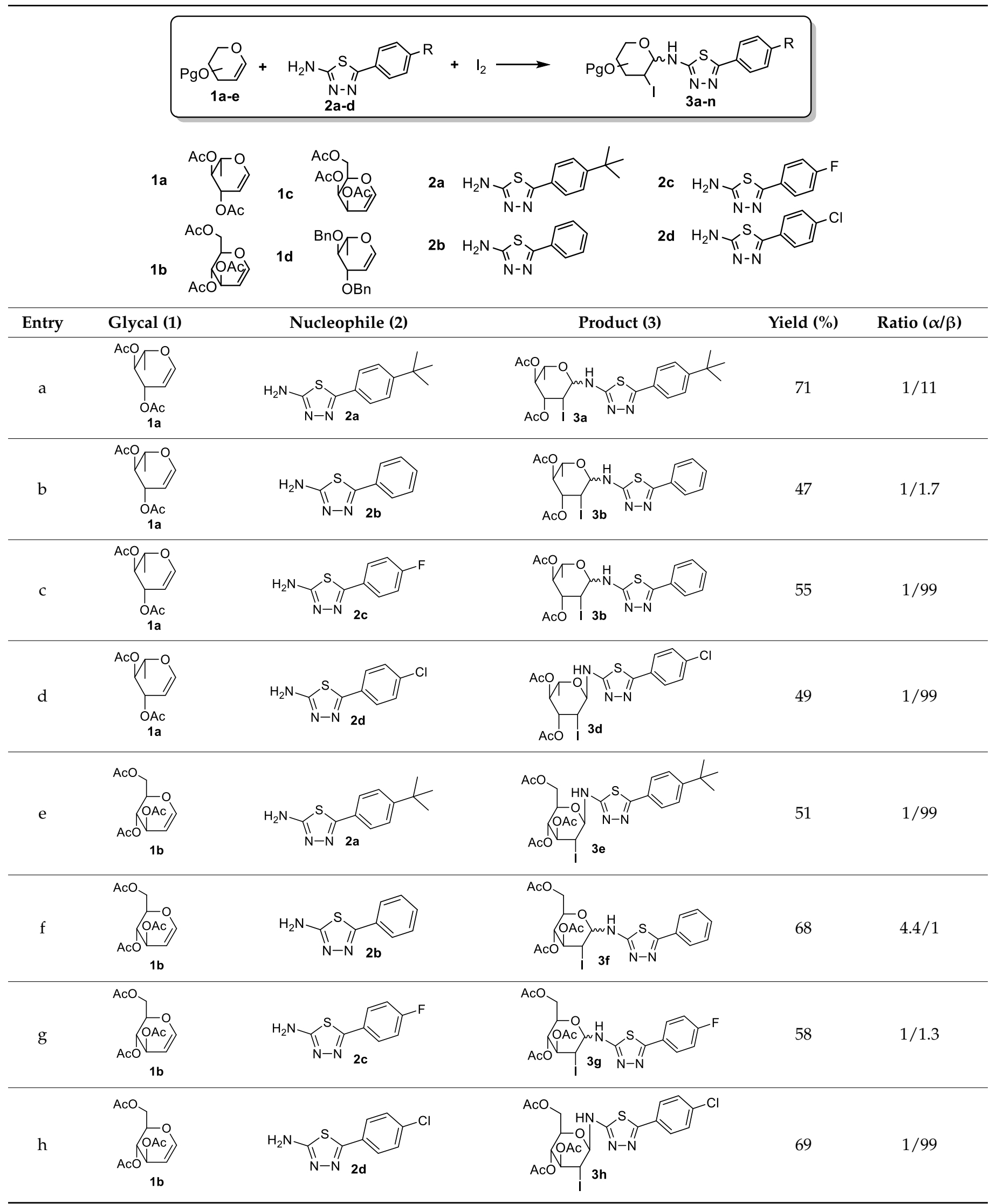


Table 2. Cont.

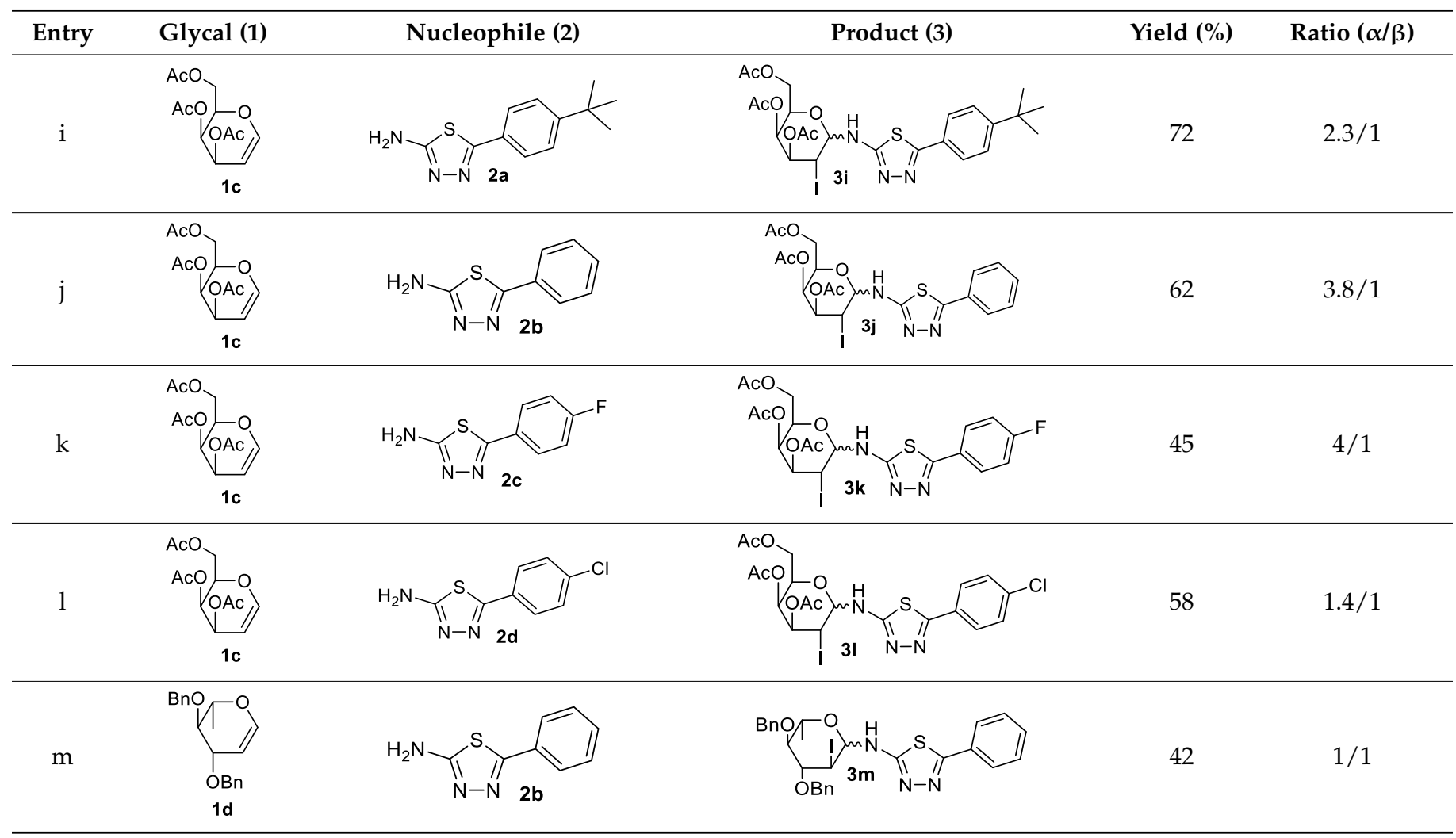

\subsubsection{Proposed Mechanism}

The anomeric configurations of all products were established based on their ${ }^{1} \mathrm{H}$ and ${ }^{13} \mathrm{C}$ NMR spectra analysis. The main products $(\mathbf{3} \mathbf{a}, \mathbf{3} \mathbf{b}, \mathbf{3} \mathbf{c}, \mathbf{3 d})$ obtained from L-rhamnal diacetate (1a) showed large values of the coupling constants (for isomer $\beta: J_{1,2}(9.6-10.4 \mathrm{~Hz}$ ), $J_{2,3}(9.6 \mathrm{~Hz})$, and $J_{3,4}(9.6 \mathrm{~Hz})$ ), indicating the trans-diaxial disposition between $\mathrm{H}-1$ and $\mathrm{H}-2, \mathrm{H}-2$ and $\mathrm{H}-3$, and $\mathrm{H}-3$ and $\mathrm{H}-4$ in the favored ${ }^{5} \mathrm{H}_{4}$ conformation. Large $J_{1,2}$ values in compounds 3a-3d signify the L-gluco configuration. The reaction of 3,4-di-O-benzylL-rhamnal (1d) with 2-amino-5-phenyl-1,3,4-thiadiazole (2b) led to 1:1 $\alpha / \beta$ mixture of L-gluco stereoisomers.

Iodine-promoted iodoamination of D-glucal (1b) with 2-amino-5-phenyl substituted 1,3,4-thiadiazole derivatives ( $\mathbf{2 a}$ and $\mathbf{2 d}$ ) was highly stereoselective, affording the $\beta-1,2-$ trans isomer of D-glucose ( $\mathbf{3} \mathbf{e}$ and $\mathbf{3 h}$ ) in moderate yields (Table 2, Entry $\mathbf{e}$ and $\mathbf{h})$. Under the same conditions, D-galactal (1c) was transformed into an inseparable mixture of 2deoxy-2-iodo- $\alpha$ / $\beta$-galacto N-glycosides (Table 2, Entry $\mathbf{i}, \mathbf{j}, \mathbf{k}$, and $\mathbf{l}$ ) in modest $45 \%-72 \%$ overall yields (Table 2). These last compounds were identified from the ${ }^{1} \mathrm{H}$ NMR proton coupling constants (for isomer $\alpha$ : $J_{1,2}=7.8-8.8 \mathrm{~Hz}, J_{2,3}=3.0-3.6 \mathrm{~Hz}, J_{3,4}=5.4-6.0 \mathrm{~Hz}$, and for isomer $\beta: J_{1,2}=8.4-10.8 \mathrm{~Hz}, J_{2,3}=5.6 \mathrm{~Hz}, J_{3,4}=3.2 \mathrm{~Hz}$ ).

The electrophilic addition of halogens to cyclic enol ethers has been investigated earlier by Lemieux and Fraser-Reid [39], who proposed a general mechanism involving the initial formation of carbenium ions which, upon nucleophilic attack by halide ion, give mainly the products of thermodynamic control. Later on, it has been shown that the product formation is under kinetic control and that the stereoselectivity depends on the solvent polarity $[7,9,10]$, the structure of the enol ether, and the nature of the halogen [16,40-42].

To improve the stereoselectivity of glycosylation reactions involving glycals, directing groups such as $\mathrm{Cl}, \mathrm{Br}$, and I are introduced. Most commonly, a directing group is temporarily introduced at C-2, and the acceptor is then incorporated at C-1. An example is NISor NBS-mediated glycosylation developed by Thiem et al. These protocols have found widespread use in the construction of complex amine-containing N-glycosides $[39,43]$. 
The addition of halogen to double bonds is expected to occur by a bimolecular process, with the approach of a halogen molecule perpendicularly to the system of the vinyl ether from both site of a molecule plane, and the compound formed may rearrange in the rate-limiting step to intermediate ions (ion pairs, open carbocation, or carboxonium ion) which, according to their relative reactivities, control the stereochemical course of the reaction (Scheme 2).

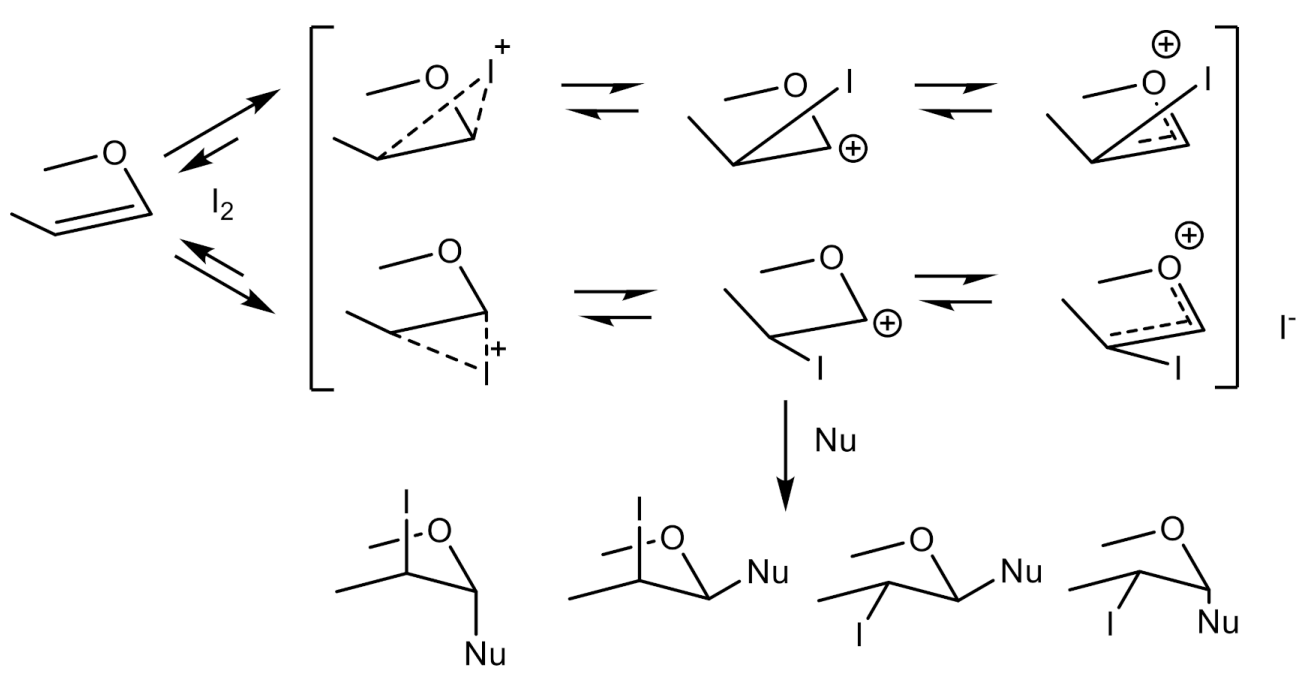

Scheme 2. Addition of iodine to the double bond of glycals followed glycosylation.

Unsaturated pyranoid rings are conformationally more flexible than saturated ones. Therefore, even insignificant changes to the spatial disposition of substituents attached to the ring may give rise to changes in the ${ }^{4} \mathrm{H}_{5},{ }^{5} \mathrm{H}_{4}$ conformational equilibrium of glycals. The factor affecting the conformational equilibrium of glycals is the 1,3-diaxial interactions destabilizes the ${ }^{5} \mathrm{H}_{4}$ form of D-glycals with the C-3 and C-5 substituents in the cis orientation [44].

Compounds 1a exist mainly in the ${ }^{5} \mathrm{H}_{4}$ conformation (Scheme 2), where all of the substituents have quasiequatorial orientations. In the ${ }^{4} \mathrm{H}_{5}$, the acetoxyl group at $\mathrm{C}-4$ is in the quasiaxial disposition, and this destabilizes this structure.

Stereoselectivity of the iodonium-promoted electrophile addition to glycals is controlled, among others, by the preferred initial attack on the glycal. It is well accepted that iodine-based electrophiles preferentially react from the top-face of glycals in their half-chair more stable conformation (Scheme 3) and the formation of bridged iodonium intermediate 1a-d, whose further trapping by nucleophiles can easily account for the regiospecificity and the high trans stereoselectivity observed [17,45-57].

The stereoselectivity of reaction depends on the structure of protecting groups. In the reaction of 3,4-di-O-benzyl-L-rhamnal (1d) a mixture of 1,2-trans L-gluco and L-manno glycosides was formed, suggesting that the addition of iodine proceeds through the stabilized carbo-oxonium ion (Scheme 3). It is proposed that the stereoselectivity of the reaction is based on a Curtin-Hammett kinetic scheme involving the in situ generation of the more reactive glycosyl halide [58].

The 1,2-trans diiodie is formed by preferential attack of $\mathrm{I}^{-}$on the oxocarbenium ion and the next activation in reaction with iodine takes place. The isomerization of iodides is a fast reaction, and an equilibrium mixture of $\alpha, \beta$-iodides is formed [59].

The 1,2-cis glycoside is formed by attack of the nucleophile on the more reactive 1,2-trans-di-iodide via an SN2-like substitution (Scheme 3) and gives 1,2-cis glycoside as the main product of the reaction. The 1,2-trans isomer can alternatively be received by the competitive formation of 2-iodo- $\alpha$-glycosyl iodide, which could then give a N-glycoside in direct SN2 substitution with the amine. On the other hand, the 1,2-trans glycoside may be obtained in the reaction of amines with carbooxonium ion. 


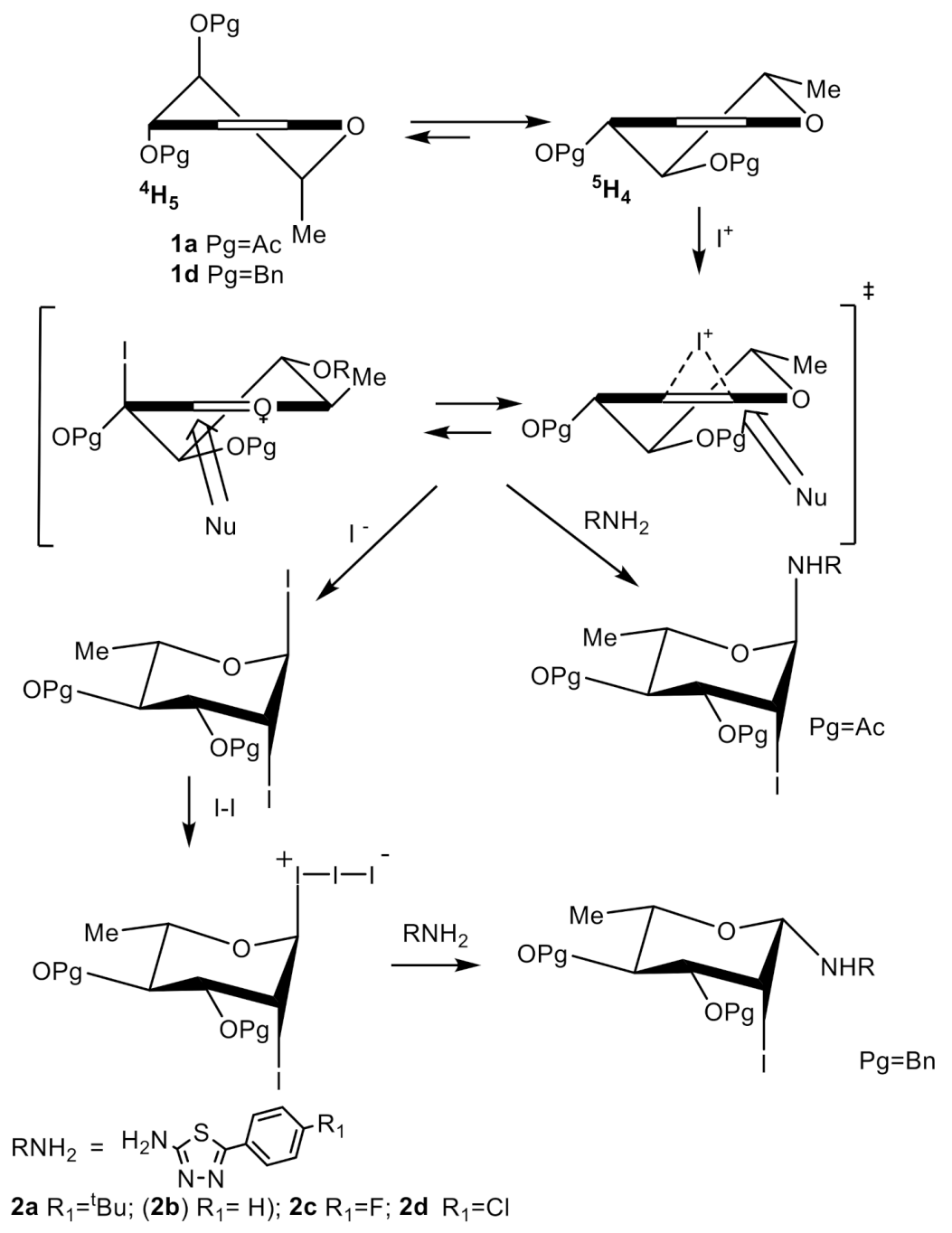

Scheme 3. Synthesis of 2-amino-1,3,4-thiadiazole glycosides starting from L-rhamnal (1a) with stereochemical effects.

Tri-O-acetyl-D-glucal (1b) exists mainly in the ${ }^{5} \mathrm{H}_{4}$ conformation (Scheme 4), and all of the substituents in $\mathbf{1 b}$ have quasiequatorial orientations. The main product, as in the bromination of glucal in Priebe et al.'s experiments [59], was compound having the $\alpha$-Dmanno configuration. This result may be explained by the formation of bridged iodonium ions that induce the attack of iodide from the opposite side (trans opening), affording the production of the trans configuration ( $\beta$-gluco iodide). The fast equilibration leads to the mixture of $\alpha / \beta$ iodides, and the nucleophilic substitution of the anomeric carbon atom by attack of 4-chloro or 5-tertbutyl substituted derivatives is controlled by steric effects. The preferred reaction by equatorial attack leads to cis $\beta$-manno glycoside formation [60].

The results of galactal 1c are opposite to the results presented above. The main products are 1,2-cis glycosides. The overall results were very close to those for the bromination of tri-O-acetyl-D-galactal, indicating that electronic effects rather than purely steric effects of the C-6 substituent are responsible for the product distribution during the bromination of glycals [15-17], where galactals with electron-withdrawing substituents at C-6 gave $\sim 90 \%$ of the trans addition products [16]. The approach of iodine from above the molecular plane leads to the $\beta$-galacto isomer and is energetically more favorable than when the attack is from below the plane of the molecule. Due to steric reasons, the $S_{N} 2$ substitution of $\mathrm{I}_{3}$ led to the $\alpha$-D-galacto isomer. 


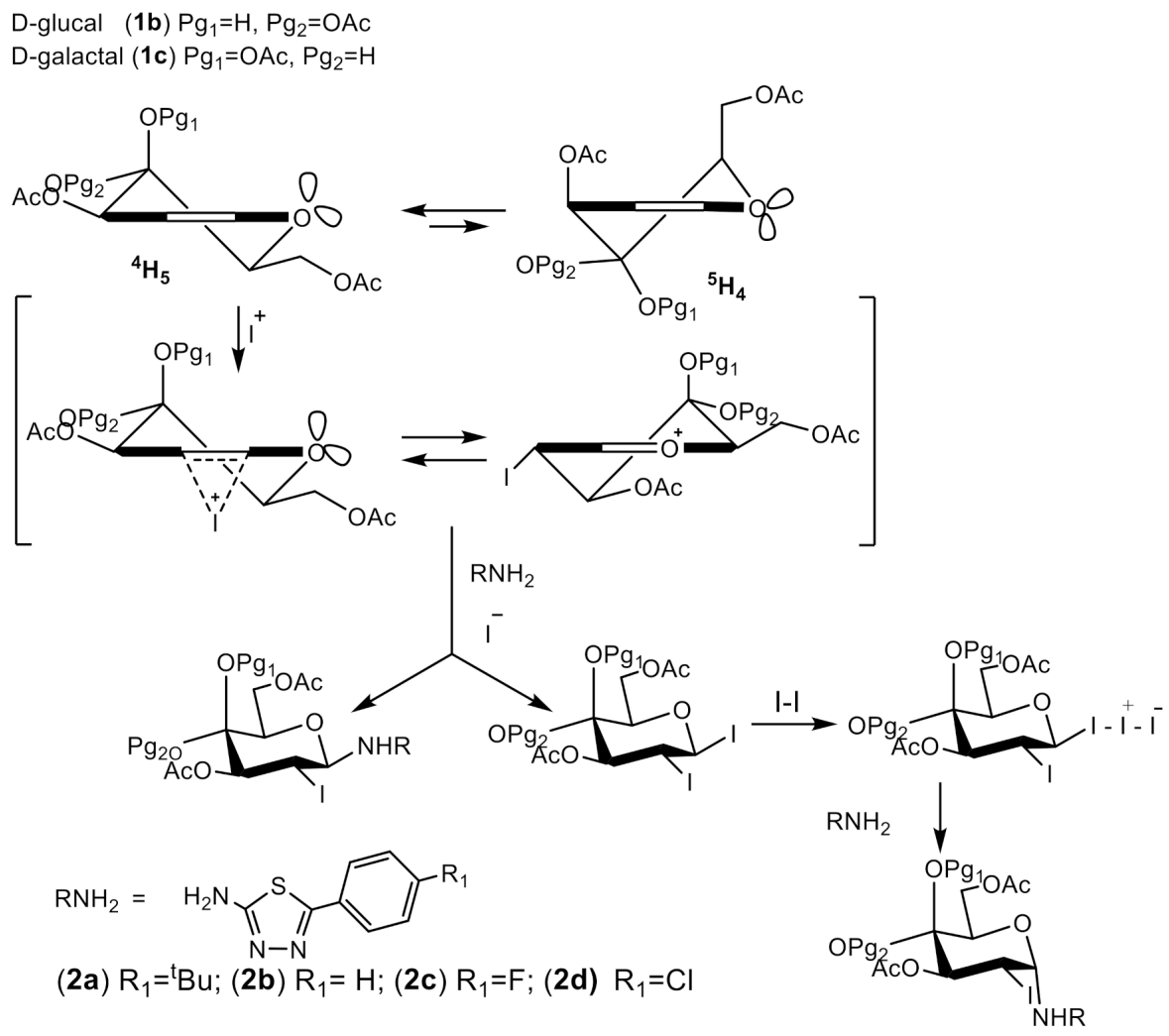

Scheme 4. Synthesis of 1,3,4-thiadiazole derivative glycosides starting from D-glucal (1b) and D-galactal (1c) with stereochemical effects.

\subsection{Biological Evaluation and Anticancer Screening}

\subsubsection{Viability of Cancer Cell Lines}

The influences of the compounds on three types of cancer cell lines (i.e., MCF-7, HCT116, and HeLa) were determined with MTT assay. After a $72 \mathrm{~h}$ incubation with the tested compounds, the cells' viabilities were measured and presented as Survival Fraction $\mathrm{s}(\mathrm{SF})$ in Figures 2-4.
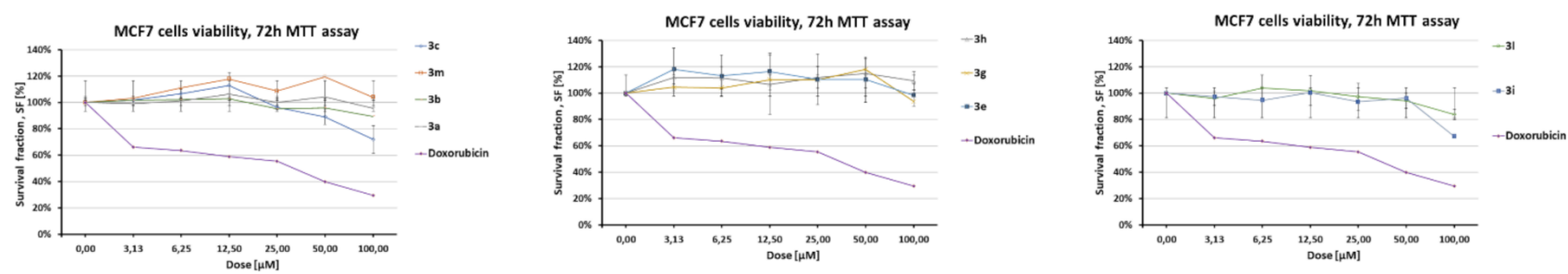

Figure 2. SF of MCF-7 cells after $72 \mathrm{~h}$ of incubation with different doses of the tested compounds $(0-100 \mu \mathrm{M})$ and doxorubicin as a positive control. The results were presented as the mean values from 3 experiments $\pm \mathrm{SD}$.
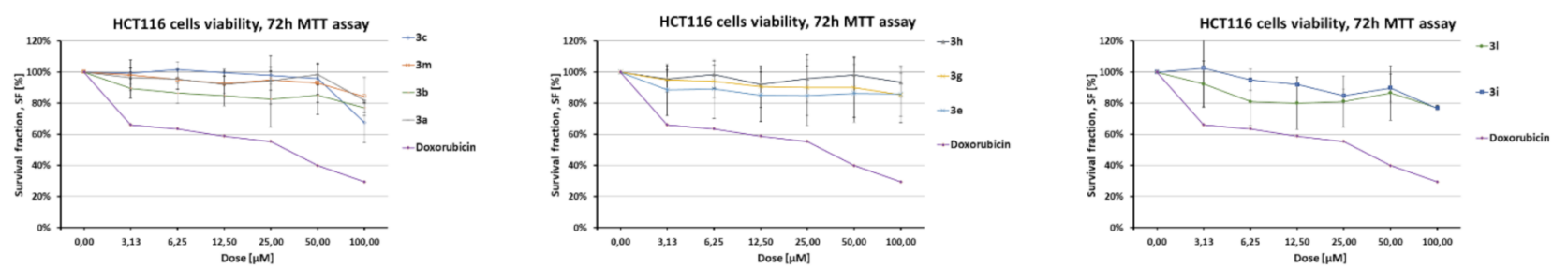

Figure 3. SF of HCT116 cells after $72 \mathrm{~h}$ of incubation with different doses of the tested compounds $(0-100 \mu \mathrm{M})$ and doxorubicin as a positive control. The results were presented as the mean values from 3 experiments \pm SD. 

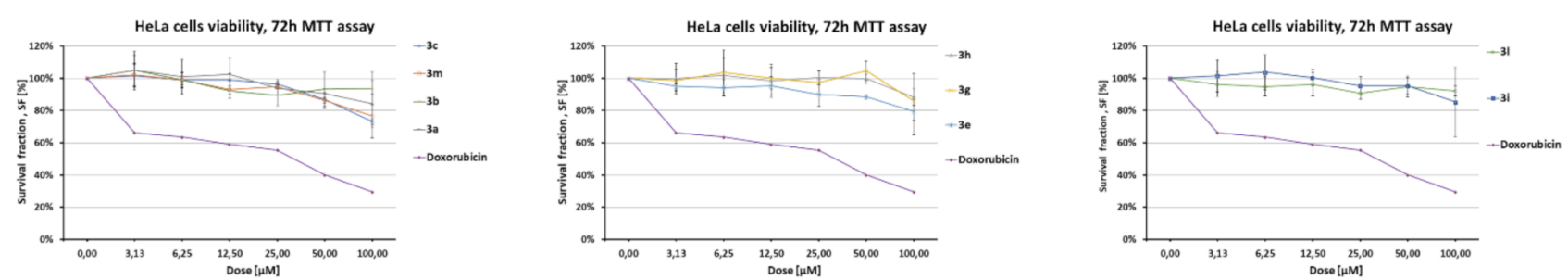

Figure 4. SF of HeLa cells after $72 \mathrm{~h}$ of incubation with different doses of tested compounds $(0-100 \mu \mathrm{M})$ and doxorubicin as a positive control. The results were presented as the mean values from 3 experiments \pm SD.

The results from the MTT assay for MCF-7 cells did not allow the $\mathrm{IC}_{50}$ calculation. However, in the case of two compounds ( $3 \mathbf{c}$ and $3 \mathbf{j}$ ), the SF of the cells decreased significantly at the highest doses (Figure 2).

Based on the results obtained for the HCT116 cell line, we concluded that this cell line was more sensitive to the tested compounds than the MCF-7 cell line, as can be seen in Figure 3.

In the case of HeLa cells, the effect of the compounds on the SF value was visible for most of the compounds, but it was not as strong as in the case of HCT116 cells (Figure 4).

\subsubsection{Cytostatic Effects on Cancer Cell Lines followed by Cell Cycle}

Although the MTT assay did not deliver clear results for the cytotoxicity of the tested compounds, the effect of lowered viabilities may have been caused by the cell cycle arrest. For a better interpretation of the possible effects, we decided to perform flow cytometry analysis for the highest doses of the compounds $(100 \mu \mathrm{M})$. The typical histograms of DNA content in cells are presented in Supplementary materials (Figure S1).

In the case of MCF-7 cells, some of the tested compounds (3a and 3c) influenced the cell cycle distribution and increased the number of cells in the sub-G1 phase, which corresponds to the dead cells (Figure 5). Furthermore, we observed a visible cell cycle arrest in the G0/G1 phase after the exposition of the cells on the compounds $\mathbf{3 f}, \mathbf{3 g}$, and $\mathbf{3 h}$.
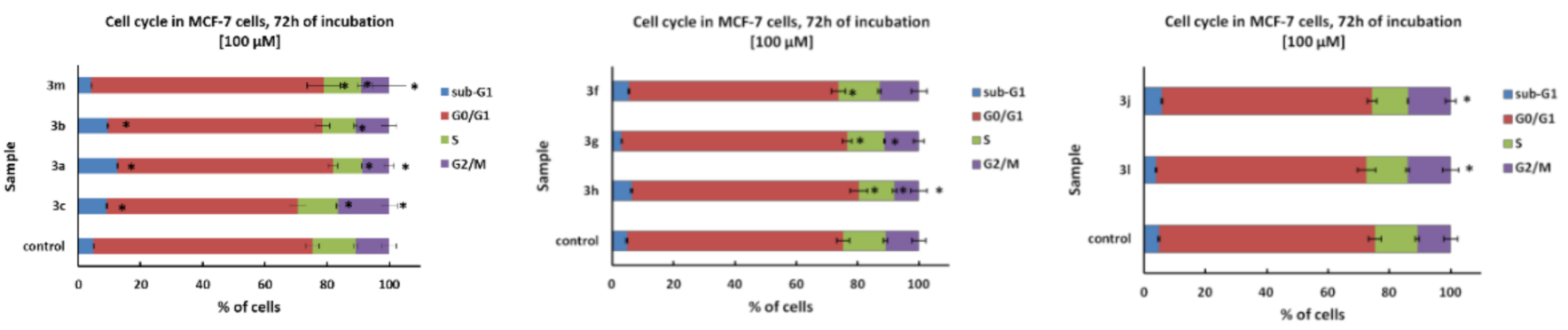

Figure 5. Cell cycle in MCF-7 cells after a 72h incubation with compounds with the concentration of $100 \mu \mathrm{M}$. The results were presented as mean value \pm SD. The statistical analysis was based on a t-test, and a $p$-value less than 0.05 was considered statistically significant in comparison to the untreated controls (indicated with a star).

Cells responded with more visible cytostatic and cytotoxic effects (Figure 6). For a panel of 3a, 3b $3 \mathbf{c}$, and $3 \mathrm{~m}$ compounds, the number of cells in the sub-G1 phase increased. Additionally, the lowering of the number of cells in the $\mathrm{S}$ phase and cell cycle arrest in the G2/M phase indicated the DNA damage with inhibition of the replication process.

In the case of the HeLa cell line, we observed a significant increase in the number of cells in the sub-G1 phase, which suggests lethal effects of the tested compounds on this cell line (Figure 7).

We decided to further investigate the type of cell death for each cell line with Annexin $\mathrm{V}$ with PI assay, which allows to distinguish necrosis from apoptosis. 

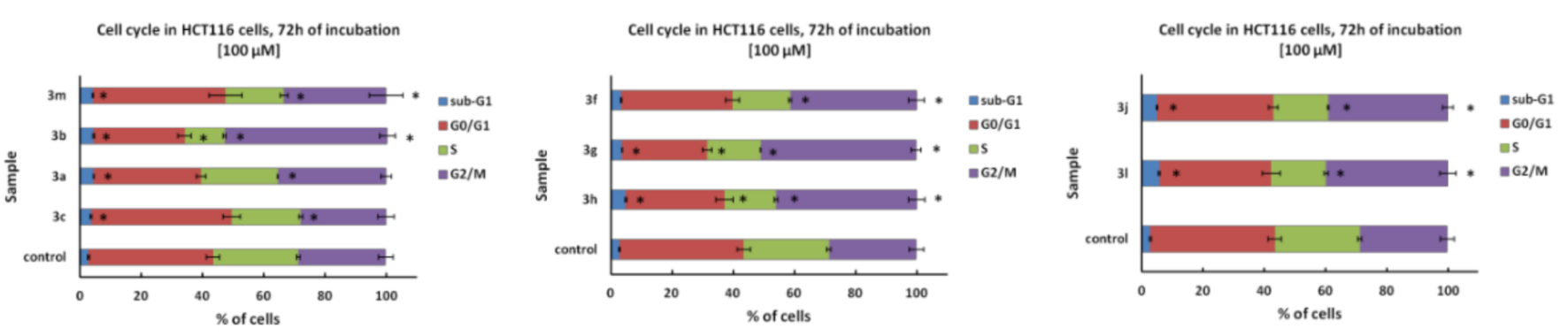

Figure 6. Cell cycle in HCT116 cells after a $72 \mathrm{~h}$ incubation with compounds with the concentration of $100 \mu \mathrm{M}$. The results were presented as mean value $\pm \mathrm{SD}$. The statistical analysis was based on a t-test, and a $p$-value less than 0.05 was considered statistically significant in comparison to the untreated controls Table 3 (indicated with a star).

Table 3. The comparison of the cytotoxic effects of $\mathbf{3 a}-\mathbf{3 c}, \mathbf{3 f}-\mathbf{3 h}, \mathbf{3} \mathbf{j}, \mathbf{3 l}$ and $\mathbf{3 m}$ derivatives against MCF-7, HCT116, and HeLa cell lines.

\begin{tabular}{|c|c|c|c|c|c|c|c|c|c|}
\hline \multirow[b]{2}{*}{ Compound } & \multicolumn{3}{|c|}{ MCF-7 } & \multicolumn{3}{|c|}{ HCT116 } & \multicolumn{3}{|c|}{ HeLa } \\
\hline & $\begin{array}{c}\text { MTT } \\
\text { (Compound conc. } \\
100 \mu \mathrm{M})\end{array}$ & $\begin{array}{l}\text { Cells in } \\
\text { sub-G1 } \\
\text { Phase }\end{array}$ & $\begin{array}{c}\text { Early } \\
\text { Apoptotic } \\
\text { Cells }\end{array}$ & $\begin{array}{c}\text { MTT } \\
\text { (Compound conc. } \\
100 \mu \mathrm{M})\end{array}$ & $\begin{array}{c}\text { Cells in } \\
\text { sub-G1 } \\
\text { Phase }\end{array}$ & $\begin{array}{l}\text { Early } \\
\text { Apoptotic } \\
\text { Cells }\end{array}$ & $\begin{array}{c}\text { MTT } \\
\text { (Compound conc. } \\
100 \mu \mathrm{M})\end{array}$ & $\begin{array}{l}\text { Cells in } \\
\text { sub-G1 } \\
\text { Phase }\end{array}$ & $\begin{array}{c}\text { Early } \\
\text { Apoptotic } \\
\text { Cells }\end{array}$ \\
\hline $3 a$ & $(-)$ & $\uparrow \uparrow$ & $\downarrow$ & $\downarrow$ & $\uparrow$ & $\uparrow \uparrow$ & $(-)$ & $\uparrow \uparrow \uparrow$ & $\uparrow \uparrow \uparrow$ \\
\hline $3 b$ & $(-)$ & $\uparrow \uparrow$ & $\downarrow$ & $\downarrow$ & $\uparrow$ & $\uparrow \uparrow$ & $\downarrow$ & $\uparrow \uparrow \uparrow$ & $\uparrow \uparrow$ \\
\hline $3 c$ & $\downarrow \downarrow$ & $\uparrow \uparrow$ & $\uparrow$ & $\downarrow \downarrow$ & $\uparrow$ & $(-)$ & $\downarrow \downarrow$ & $\uparrow \uparrow \uparrow$ & $\uparrow \uparrow$ \\
\hline $3 f$ & $(-)$ & $\uparrow$ & $\downarrow$ & $\downarrow$ & $(-)$ & $\uparrow \uparrow$ & $\downarrow$ & $\uparrow \uparrow \uparrow$ & $\uparrow \uparrow$ \\
\hline $3 g$ & $(-)$ & $\downarrow$ & $\downarrow$ & $\downarrow$ & $(-)$ & $\uparrow \uparrow$ & $\downarrow$ & $\uparrow \uparrow \uparrow$ & $\uparrow \uparrow$ \\
\hline $3 \mathrm{~h}$ & $(-)$ & $\uparrow$ & $\downarrow$ & $(-)$ & $\uparrow$ & $\downarrow$ & $\downarrow$ & $\uparrow \uparrow \uparrow$ & $\uparrow \uparrow$ \\
\hline $3 j$ & $\downarrow \downarrow$ & $\uparrow$ & $\downarrow$ & $\downarrow$ & $\uparrow \uparrow$ & $\uparrow \uparrow$ & $\downarrow$ & $\uparrow \uparrow \uparrow$ & $\uparrow \uparrow$ \\
\hline 31 & $\downarrow$ & $(-)$ & $\downarrow$ & $\downarrow$ & $\uparrow \uparrow$ & $\uparrow \uparrow$ & $(-)$ & $\uparrow \uparrow \uparrow$ & $\uparrow \uparrow$ \\
\hline $3 m$ & $(-)$ & $(-)$ & $\downarrow$ & $\downarrow$ & $\uparrow$ & $\uparrow$ & $\downarrow$ & $\uparrow \uparrow \uparrow$ & $\uparrow \uparrow$ \\
\hline
\end{tabular}

$(-) ;(-) ;(-)$-no effect. $\downarrow$-decrease in SF value. The number of arrows indicates the strength of the effect (single weak, double stronger). $\uparrow-$ increase in the number of cells in sub-G1 phase compared to cells in the control group $\downarrow$-a decrease in the number of cells in sub-G1 phase compared to cells in the control group. The number of arrows indicates the strength of the effect (single: weak, double: stronger, triple: the strongest). $\uparrow$-increase in the number of early apoptotic cells compared to cells in the control group $\downarrow$-a decrease in the number of early apoptotic cells compared to cells in the control group. The number of arrows indicates the strength of the effect (single: weak, double: stronger, triple: the strongest).
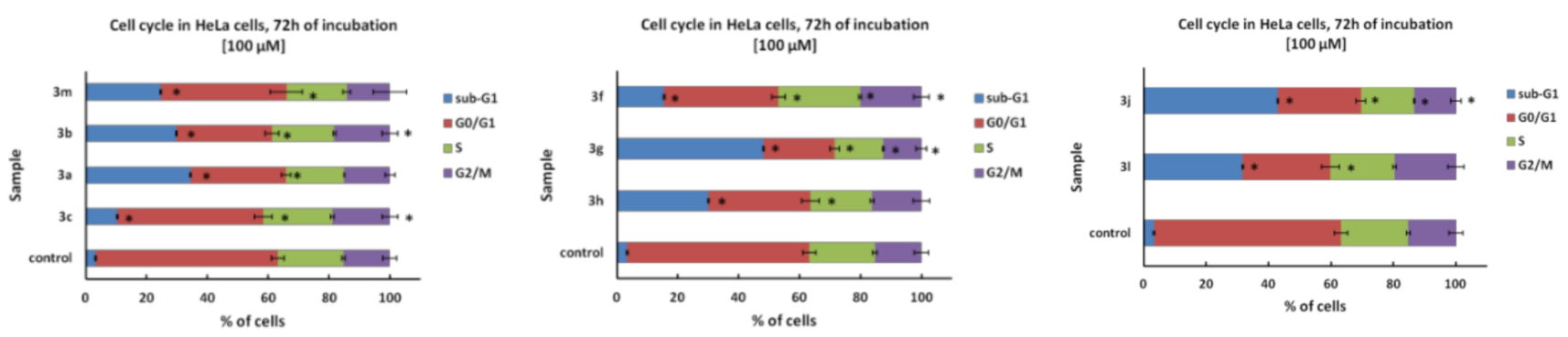

Figure 7. Cell cycle in HeLa cells after a $72 \mathrm{~h}$ incubation with compounds with the concentration of $100 \mu \mathrm{M}$. The results were presented as mean value $\pm \mathrm{SD}$. The statistical analysis was based on a t-test, and a $p$-value less than 0.05 was considered statistically significant in comparison to the untreated controls (indicated with a star).

\subsubsection{Death Mechanism Induced in Cancer Lines}

To conclude the cell death mechanism, we performed Annexin V with PI assay after a $72 \mathrm{~h}$ incubation of all the cell lines with the analyzed compounds in the concentration of $100 \mu \mathrm{M}$. The typical dot plots from Annexin-V apoptosis assay from cells are presented in Supplementary material (Figure S2).

Based on the results, for the MCF-7 cell line (Figure 8), we concluded that the tested compounds did not exhibit any pro-apoptotic effects. 

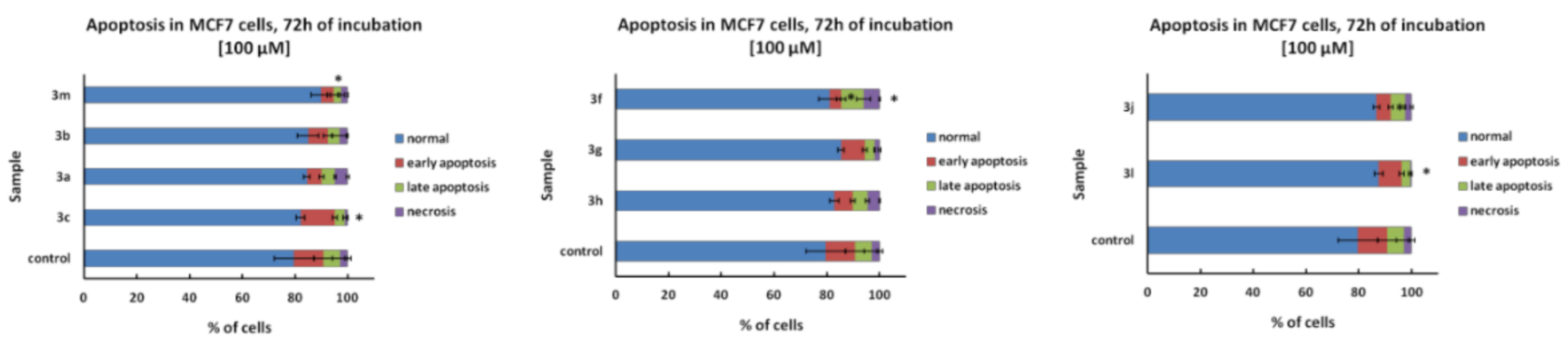

Figure 8. Apoptosis in MCF-7 cells after a $72 \mathrm{~h}$ incubation with compounds with a concentration of $100 \mu \mathrm{M}$. The results were presented as mean value $\pm \mathrm{SD}$. The statistical analysis was based on a t-test, and a $p$-value less than 0.05 was considered statistically significant in comparison to the untreated controls (indicated with a star).

In contrast to the MCF-7, the HCT116 cells (Figure 9)responded with apoptosis. It indicated that the analyzed compounds exhibit pro-apoptotic activity against this cell line.
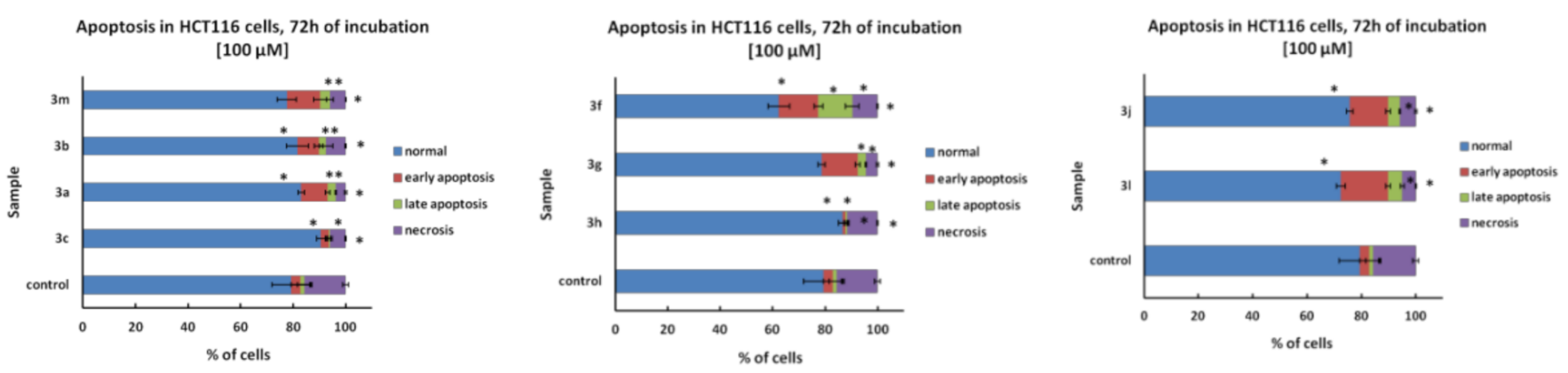

Figure 9. Apoptosis in HCT116 after a $72 \mathrm{~h}$ incubation with compounds with a concentration of $100 \mu \mathrm{M}$. The results were presented as mean value $\pm \mathrm{SD}$. The statistical analysis was based on a t-test, and a $p$-value less than 0.05 was considered statistically significant in comparison to the untreated controls (indicated with a star).

Similarly to the HCT116 cells, the tested compounds have exhibited a pro-apoptotic effect on the HeLa cell line. However, in most of the cases, the effect was much stronger (Figure 10).
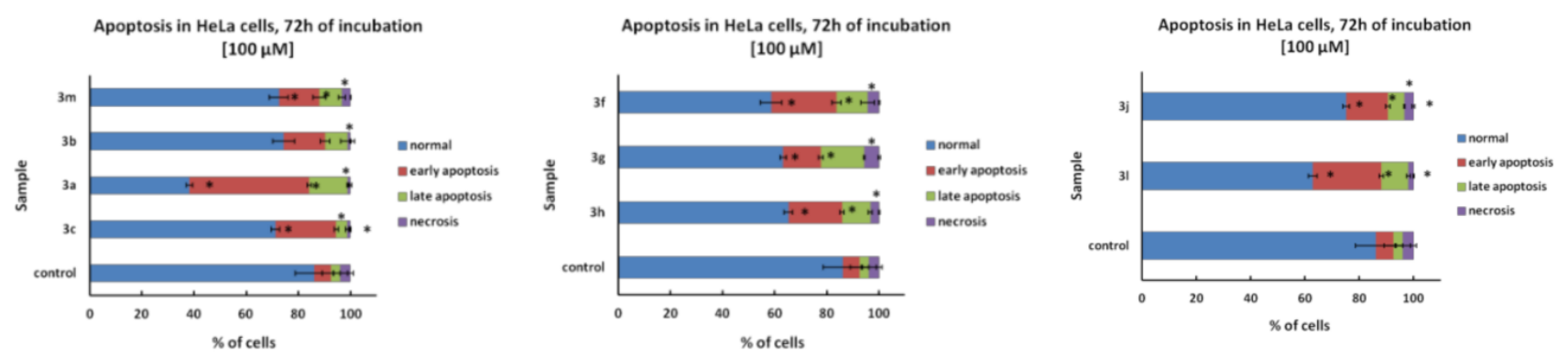

Figure 10. Apoptosis in HeLa after a 72h incubation with compounds with the concentration of $100 \mu \mathrm{M}$. The results were presented as mean value $\pm \mathrm{SD}$. The statistical analysis was based on a t-test, and a p-value less than 0.05 was considered statistically significant in comparison to the untreated controls (indicated with a star).

The efficient formation of glycosidic linkages has played an important role in the development of modern synthetic carbohydrate chemistry. Among the various types of donors that can be employed for the construction of glycosidic bonds, glycosyl iodides should now be viewed as versatile glycosylation reagents [61,62].

The research found the ineffectiveness of the conventional methods for the preparation of $\mathrm{N}$-glycosides of 2-deoxy monosaccharides in the nucleophilic substitution reaction with the participation of very weakly nucleophilic amine thiadiazole derivatives. The 
publication presents an efficient method for glycosylation starting from glycals, with the activation leading to the glycosyl donor taking place with 2eq of iodine, preferably in a polar solvent such as THF. It has been shown that by the appropriate optimization of conditions, it is possible to obtain highly stereoselective products of rhamnal and glucal. The advantage of this method is the use of an easily available, cheap, and environmentally friendly reagent, molecular iodine.

The biological activity of the tested compounds was determined based on the MTT assay complemented with flow cytometry analysis. The combination of these methods allows for the detection of cytotoxic, cytostatic, and lethal effects of the compounds on the analyzed cell lines.

The performed MTT assay indicated that the effect of the compounds depended significantly on the tested cell line (Table 3). Among the tested cell lines, MCF-7 cells were the most resistant and HCT116 cells were the most sensitive to the tested compounds. Unfortunately, the compounds exhibited low biological activity and hence neither the $\mathrm{IC}_{50}$ parameter nor the selectiveness of the compounds against the tested cell lines could be evaluated for the examined doses. Nevertheless, based on the SF values, we observed that the highest concentrations of the compounds $(100 \mu \mathrm{M})$ inhibited the cells proliferation. Because of it, we decided to test the effect of the compounds on the cell cycle only for the highest concentrations.

According to the biological assays, in the case of MCF-7 cells, despite the low cytotoxic effect of the compounds, we did not observe any cytostatic or pro-apoptotic effect. During the cell cycle analysis, we detected a slight increase in the number of cells present in the sub-G1 phase or an increase in cells arrested in the G0/G1 phase. Furthermore, there was no increase in apoptotic nor necrotic cells. Nevertheless, the detected effect was not significant when compared to the untreated control.

More promising effects were detected in the case of other cell lines. The cell line, which was the most sensitive in the MTT assay (HCT116) responded with both cytostatic and cytotoxic effects. During the cell cycle analysis, we observed an increase in the number of cells in the sub-G1 fractions, however, the strongest effect was visible in the inhibition of the $\mathrm{S}$ phase and the arrest of the cells in the G2/M phase. Additionally, we detected an increase in cells in the early apoptosis, which suggests that the compounds have pro-apoptotic activity against the HCT116 cell line.

The most auspicious effects were observed for the HeLa cells. Similarly to the HCT116 cell line, the compounds caused cytotoxic and cytostatic effects on this cell line. Moreover, in the case of the HeLa cells, we detected an increase in the number of cells in the sub-G1 phase. Furthermore, Annexin V staining proved that the cells underwent both apoptotic cell deaths.

Based on the carried out experiments we noticed a tissue-dependent effect of the tested compounds and we concluded that they exhibit a cytotoxic effect on the MCF-7, HCT116, and HeLa cell lines, a cytostatic effect on the HCT116 and HeLa cell lines, and a lethal effect on the HeLa cell line.

Our results indicate that the tested compounds in their current form cannot be exploited as drugs, however, they stand as promising models for further modification. In order to improve the antitumor activity of the conjugates, structural modifications are necessary. Especially interesting is applying in biological tests deprotected conjugates, it should affect the solubility of these derivatives in the applied medium. Another approach is the synthesis of the derivatives where a sugar moiety is linked to a thiadiazole derivative via an aliphatic, aromatic-aliphatic, or aromatic linker.

\section{Materials and Methods}

\subsection{Chemistry}

General. All reagents were purchased from Merck (Darmstadt, Germany), Acros Organics (Geel, Belgium), Alpha Aesar (Haverhill, USA), and Sigma-Aldrich (Taufkirchen, Germany) and used without further purification. A column chromatography was per- 
formed on a silica gel packed column (Kieselgel 60 0.040-0.063 mm, 230-400 mesh, Merck, Darmstadt, Germany). Solvents for chromatography (n-hexane, ethyl acetate, methanol, dichloromethane) were distilled before use. Thin layer chromatography was performed on plates coated with silica gel $60 \mathrm{~F}_{254}$ (Merck, Darmstadt, Germany); detection was carried out with either ultraviolet light $(254 \mathrm{~nm})$ or spraying with a solution of phosphomolybdic acid, a basic potassium permanganate solution, or ethanolic solution of concentrated $\mathrm{H}_{2} \mathrm{SO}_{4}$, with subsequent heating. Optical rotations were measured with a JASCO P-2000 polarimeter using a sodium lamp $(589.3 \mathrm{~nm})$ at room temperature. Melting points were measured on a Stuart SMP3 melting point apparatus. The ${ }^{1} \mathrm{H}$ NMR and ${ }^{13} \mathrm{C} \mathrm{NMR}$ spectra were recorded on an Agilent $400 \mathrm{MHz}$ spectrometer and Varian $600 \mathrm{MHz}$ spectrometer in DMSO- $d_{6}$ or $\mathrm{CDCl}_{3}$ using tetramethylsilane (TMS) as an internal standard. Chemical shifts are reported as $\delta$ values (ppm). FT-IR spectra were recorded between 4000 and $650 \mathrm{~cm}^{-1}$ using an FT-IR Nicolet 6700 apparatus (IET, Mundelein, USA) with a Smart iTR accessory. HRMS spectra were recorded on a Waters ACQUITY UPLC/Xevo G2QT instrument.

General procedure for iodination of glycals:

To a solution of glycal (1a-d: $1.0 \mathrm{eq})$ in THF (2 mL), 2-amino-1,3,4-thiadiazole derivative $(2 \mathbf{a}-\mathbf{d}: 2.0 \mathrm{eq})$ and $\mathrm{I}_{2}(2.0 \mathrm{eq})$ were added. The reaction was stirred at room temperature for 1.5h. The TLC (Toluene:EtOAc, 2:1 v/v) indicated total consumption of glycal. The solvent was removed under reduced pressure, and the residue was purified by silica gel column chromatography (gradient from toluene to toluene:EtOAc, 10:1 v/v) to give products as a pale yellow oil being a mixture of anomers.

5-(4-(tert-buthyl)phenyl)-N-(3,4-di-O-acetyl-2-deoxy-2-iodo- $\alpha / \beta$-L-rhamnopyranosyl)-1,3,4thiadiazol-2-amine (3a): Starting from 3,4-di-O-acetyl-L-rhamnal (1a: $80 \mathrm{mg}, 0.383 \mathrm{mmol})$ and 2-amino-5-(4-tert-buthylphenyl)-1,3,4-thiadiazole (2a: $174 \mathrm{mg}, 0.746 \mathrm{mmol})$, yield 71\% $(62.9 \mathrm{mg})$; ratio of anomers $(\alpha: \beta=1: 11) ;{ }^{1} \mathrm{H} \mathrm{NMR}\left(400 \mathrm{MHz}, \mathrm{CDCl}_{3}\right): \delta 7.58-7.56(\mathrm{~m}, 4 \mathrm{H}$, Ph), 7.46-7.43 (m, 4H, Ph), $6.04(\mathrm{~d}, J=4.6 \mathrm{~Hz}, 1 \mathrm{H}, \mathrm{H}-1 \alpha), 5.90(\mathrm{~d}, J=10.4 \mathrm{~Hz}, 1 \mathrm{H}, \mathrm{H}-1 \beta), 5.44$ $(\mathrm{dd}, J=9.2 \mathrm{~Hz}, 11.2 \mathrm{~Hz}, 1 \mathrm{H}, \mathrm{H}-4 \alpha), 4.87$ (t, $J=9.6 \mathrm{~Hz}, 1 \mathrm{H}, \mathrm{H}-3 \alpha), 4.69-4.62(\mathrm{~m}, 1 \mathrm{H}, \mathrm{H}-2 \alpha)$, $3.87(\mathrm{dq}, J=6 \mathrm{~Hz}, 10 \mathrm{~Hz}, 1 \mathrm{H}, \mathrm{H}-5 \alpha), 2.12\left(\mathrm{~s}, 3 \mathrm{H}, \mathrm{COCH}_{3}\right), 2.08\left(\mathrm{~s}, 3 \mathrm{H}, \mathrm{COCH}_{3}\right), 2.06(\mathrm{~s}, 3 \mathrm{H}$, $\left.\mathrm{COCH}_{3}\right), 2.05\left(\mathrm{~s}, 3 \mathrm{H}, \mathrm{COCH}_{3}\right), 1.34\left(\mathrm{~s}, 9 \mathrm{H}, \mathrm{C}\left(\mathrm{CH}_{3}\right)_{3}\right), 1.26\left(\mathrm{~d}, J=6 \mathrm{~Hz}, 1 \mathrm{H}, \mathrm{CH}_{3} \alpha\right)$, and 1.19 $\left(\mathrm{d}, 1 \mathrm{H}, J=6.4 \mathrm{~Hz}, \mathrm{CH}_{3} \beta\right) ;{ }^{13} \mathrm{C}$ NMR $\left(100 \mathrm{MHz} \mathrm{CDCl}_{3}\right): \delta 170.0\left(\mathrm{COCH}_{3}\right), 169.7\left(\mathrm{COCH}_{3}\right)$, $167.2(\mathrm{~S}-\mathrm{C}=\mathrm{N}), 154.4(\mathrm{~N}-\mathrm{C}=\mathrm{N}), 127.4(\mathrm{Ph}), 126.2(\mathrm{Ph}), 126.0(\mathrm{Ph}), 81.6(\mathrm{C}-1), 76.3(\mathrm{C}-3), 74.0$ (C-5), $72.7(\mathrm{C}-4), 35.1\left(\mathrm{C}\left(\mathrm{CH}_{3}\right)_{3}\right), 31.3\left(\mathrm{C}\left(\mathrm{CH}_{3}\right)_{3}\right), 29.8(\mathrm{C}-2), 21.0\left(\mathrm{COCH}_{3}\right), 20.9\left(\mathrm{COCH}_{3}\right)$, and 17.5 (C-6); HRMS m/z calcd for $\left(\mathrm{C}_{22} \mathrm{H}_{28} \mathrm{IN}_{3} \mathrm{O}_{5} \mathrm{~S}+\mathrm{H}^{+}\right)$: 574.0867; found: 574.0874 .

5-phenyl-N-(3,4-di-O-acetyl-2-deoxy-2-iodo- $\alpha / \beta$-L-rhamnopyranosyl)-1,3,4-thiadiazol-2-amine (3b): Starting from 3,4-di-O-acetyl-L-rhamnal (1a: $220 \mathrm{mg}, 1.027 \mathrm{mmol}$ ) and 2-amino-5phenyl-1,3,4-thiadiazole (2b: $364 \mathrm{mg}, 2.054 \mathrm{mmol})$, yield 47\% (85.8 mg); ratio of anomers $(\alpha: \beta=1: 1.7) ;{ }^{1} \mathrm{H}$ NMR (600 MHz, $\left.\mathrm{CDCl}_{3}\right): \delta 7.70-7.68(\mathrm{~m}, 2 \mathrm{H}, \mathrm{Ph}), 7.65-7.63(\mathrm{~m}, 3 \mathrm{H}, \mathrm{Ph})$, $6.28(\mathrm{~d}, J=4.8 \mathrm{~Hz}, 1 \mathrm{H}, \mathrm{H}-1 \alpha), 5.91(\mathrm{~d}, J=10.2 \mathrm{~Hz}, 1 \mathrm{H}, \mathrm{H}-1 \beta), 5.44(\mathrm{dd}, J=9.0 \mathrm{~Hz}, 10.8 \mathrm{~Hz}$, $1 \mathrm{H}, \mathrm{H}-4 \beta), 5.32(\mathrm{dd}, J=3.6 \mathrm{~Hz}, 6 \mathrm{~Hz}, 1 \mathrm{H}, \mathrm{H}-3 \alpha), 5.10(\mathrm{t}, J=4.8 \mathrm{~Hz}, 1 \mathrm{H}, \mathrm{H}-2 \alpha), 5.04(\mathrm{t}$, $J=6.6 \mathrm{~Hz}, 1 \mathrm{H}, \mathrm{H}-4 \alpha), 4.88(\mathrm{t}, J=9.6 \mathrm{~Hz}, 1 \mathrm{H}, \mathrm{H}-3 \beta), 4.69-4.62(\mathrm{~m}, 1 \mathrm{H}, \mathrm{H}-2 \beta), 4.15-4.11(\mathrm{~m}$, $1 \mathrm{H}, 5 \alpha), 3.88(\mathrm{dq}, J=6.6 \mathrm{~Hz}, 9.6 \mathrm{~Hz}, 1 \mathrm{H}, \mathrm{H}-5 \beta), 2.18\left(\mathrm{~s}, 3 \mathrm{H}, \mathrm{COCH}_{3}\right), 2.12\left(\mathrm{~s}, 3 \mathrm{H}, \mathrm{COCH}_{3}\right)$, $2.11\left(\mathrm{~s}, 3 \mathrm{H}, \mathrm{COCH}_{3}\right), 2.06\left(\mathrm{~s}, 3 \mathrm{H}, \mathrm{COCH}_{3}\right), 1.38\left(\mathrm{~d}, \mathrm{~J}=6.6 \mathrm{~Hz}, 1 \mathrm{H}, \mathrm{CH}_{3} \alpha\right)$, and $1.28(\mathrm{~d}$, $\left.J=6 \mathrm{~Hz}, 1 \mathrm{H}, \mathrm{CH}_{3} \beta\right) ;{ }^{13} \mathrm{C} \mathrm{NMR}\left(150 \mathrm{MHz} \mathrm{CDCl}_{3}\right): \delta 170.0\left(\mathrm{COCH}_{3}\right), 169.8\left(\mathrm{COCH}_{3}\right), 169.7$ $\left(\mathrm{COCH}_{3}\right), 162.1(\mathrm{~S}-\mathrm{C}=\mathrm{N}), 147.4(\mathrm{~N}-\mathrm{C}=\mathrm{N}), 130.8(\mathrm{Ph}), 130.2(\mathrm{Ph}), 129.1(\mathrm{Ph}), 129.0(\mathrm{Ph}), 128.3$ (Ph), $126.4(\mathrm{Ph}), 126.4(\mathrm{Ph}), 76.3$ (C-1), 74.0 (C-3), 72.8 (C-2), 72.0 (C-5), 71.3 (C-4), 26.8 $(\mathrm{C}-2), 21.2\left(\mathrm{COCH}_{3}\right), 21.1\left(\mathrm{COCH}_{3}\right), 21.0\left(\mathrm{COCH}_{3}\right), 20.8\left(\mathrm{COCH}_{3}\right), 17.5(\mathrm{C}-6)$, and $17.1(\mathrm{C}-6)$; HRMS $m / z$ calcd for $\left(\mathrm{C}_{18} \mathrm{H}_{20} \mathrm{IN}_{3} \mathrm{O}_{5} \mathrm{~S}+\mathrm{H}^{+}\right)$: 518.0241; found: 518.0251 .

5-(4-fluorophenyl)-N-(3,4-di-O-acetyl-2-deoxy-2-iodo- $\beta$-L-rhamnopyranosyl)-1,3,4-thiadiazol2-amine (3c): Starting from 3,4-di-O-acetyl-L-rhamnal (1a: $137 \mathrm{mg}, 0.640 \mathrm{mmol}$ ) and 2-amino5-(4-fluorophenyl)-1,3,4-thiadiazole (2c: $250 \mathrm{mg}, 1.281 \mathrm{mmol})$, yield 55\% (68.7 mg); ratio of anomers $(\alpha: \beta=1: 99) ; \alpha^{24} \mathrm{D}=-80\left(\mathrm{c}=0.25, \mathrm{CHCl}_{3}\right) ;{ }^{1} \mathrm{H} \mathrm{NMR}\left(600 \mathrm{MHz}, \mathrm{CDCl}_{3}\right): \delta 7.65-7.62$ (m, 2H, Ph), 7.14-7.11 (m, 2H, Ph), $5.90(\mathrm{~d}, 1 \mathrm{H}, J=9.6 \mathrm{~Hz}, \mathrm{H}-1 \beta), 5.44(\mathrm{dd}, 1 \mathrm{H}, J=9.6 \mathrm{~Hz}$,

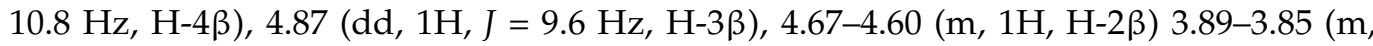
$1 \mathrm{H}, \mathrm{H}-5 \beta), 2.12\left(\mathrm{~s}, 3 \mathrm{H}, \mathrm{COCH}_{3}\right), 2.06\left(\mathrm{~s}, 3 \mathrm{H}, \mathrm{COCH}_{3}\right)$, and $1.28\left(\mathrm{~d}, 3 \mathrm{H}, J=6 \mathrm{~Hz}, \mathrm{CH}_{3} \beta\right)$; 
${ }^{13} \mathrm{C}$ NMR $\left(150 \mathrm{MHz}, \mathrm{CDCl}_{3}\right): \delta 170.0\left(\mathrm{COCH}_{3}\right), 169.7\left(\mathrm{COCH}_{3}\right), 166.7(\mathrm{~S}-\mathrm{C}=\mathrm{N}), 164.2(\mathrm{~d}$, $J=251 \mathrm{~Hz}, \mathrm{C}-\mathrm{F}), 154.8(\mathrm{~N}-\mathrm{C}=\mathrm{N}), 132.4(\mathrm{Ph}), 128.4(\mathrm{Ph}), 128.3(\mathrm{Ph}), 116.3(\mathrm{Ph}), 116.2(\mathrm{Ph})$, 83.8 (C-1), 76.3 (C-3), $74.0(\mathrm{C}-4), 72.8(\mathrm{C}-5), 27.0(\mathrm{C}-2), 21.0\left(\mathrm{COCH}_{3}\right), 20.9\left(\mathrm{COCH}_{3}\right)$, and 17.5 (C-6); HRMS $m / z$ calcd for $\left(\mathrm{C}_{18} \mathrm{H}_{19} \mathrm{FIN}_{3} \mathrm{O}_{5} \mathrm{~S}+\mathrm{H}^{+}\right)$: 536.0147 ; found: 536.0153 .

5-(4-chlorophenyl)-N-(3,4-di-O-acetyl-2-deoxy-2-iodo- $\beta$-L-rhamnopyranosyl)-1,3,4-thiadiazol2-amine (3d): Starting from 3,4-di-O-acetyl-L-rhamnal (1a: $121 \mathrm{mg}, 0.565 \mathrm{mmol}$ ) and 2amino-5-(4-chlorophenyl)-1,3,4-thiadiazole (2d: $239 \mathrm{mg}, 1.129 \mathrm{mmol}$ ), yield $49 \%$ (58.6 mg); ratio of anomers $(\alpha: \beta=1: 99) ; \alpha^{24} \mathrm{D}=-13.3\left(\mathrm{c}=0.45, \mathrm{CHCl}_{3}\right) ;{ }^{1} \mathrm{H} \mathrm{NMR}\left(600 \mathrm{MHz}, \mathrm{CDCl}_{3}\right)$ : $\delta$ 7.58-7.56 (m, 2H, Ph), 7.42-7.40 (m, 2H, Ph), $5.91(\mathrm{~d}, 1 \mathrm{H}, J=9.6 \mathrm{~Hz}, \mathrm{H}-1 \beta), 5.44(\mathrm{dd}$, $1 \mathrm{H}, J=9.6 \mathrm{~Hz}, 11.4 \mathrm{~Hz}, \mathrm{H}-4 \beta), 4.87(\mathrm{t}, 1 \mathrm{H}, J=9.6 \mathrm{~Hz}, \mathrm{H}-3 \beta), 4.65-4.59(\mathrm{~m}, 1 \mathrm{H}, \mathrm{H}-2 \beta)$ 3.89-3.85 (m, $1 \mathrm{H}, \mathrm{H}-5 \beta), 2.12\left(\mathrm{~s}, 3 \mathrm{H}, \mathrm{COCH}_{3}\right), 2.06\left(\mathrm{~s}, 3 \mathrm{H}, \mathrm{COCH}_{3}\right)$, and $1.28(\mathrm{~d}, 3 \mathrm{H}, J=6 \mathrm{~Hz}$, $\left.\mathrm{CH}_{3} \beta\right) ;{ }^{13} \mathrm{C}$ NMR $\left(150 \mathrm{MHz}, \mathrm{CDCl}_{3}\right): \delta 170.0\left(\mathrm{COCH}_{3}\right), 169.7\left(\mathrm{COCH}_{3}\right), 165.8(\mathrm{~S}-\mathrm{C}=\mathrm{N})$, $146.3(\mathrm{~N}-\mathrm{C}=\mathrm{N}), 136.9(\mathrm{C}-\mathrm{Cl}), 136.4(\mathrm{Ph}), 129.3(\mathrm{Ph}), 127.6(\mathrm{Ph}), 83.8(\mathrm{C}-1), 76.2(\mathrm{C}-3), 74.0$ (C-4), $72.8(\mathrm{C}-5), 42.7(\mathrm{C}-2), 21.0\left(\mathrm{COCH}_{3}\right), 20.9\left(\mathrm{COCH}_{3}\right)$, and 17.5 (C-6); HRMS $\mathrm{m} / \mathrm{z}$ calcd for $\left(\mathrm{C}_{18} \mathrm{H}_{19} \mathrm{ClIN}_{3} \mathrm{O}_{5} \mathrm{~S}+\mathrm{H}^{+}\right)$: 551.9851; found: 551.9855 .

5-(4-(tert-buthyl)phenyl)-N-(3,4,6-tri-O-acetyl-2-deoxy-2-iodo- $\beta$-L-glucopyranosyl)-1,3,4thiadiazol-2-amine (3e): Starting from 3,4,6-tri-O-acetyl-D-glucal (1b: $360 \mathrm{mg}, 1.322 \mathrm{mmol}$ ) and 2-amino-5-(4-tert-buthylphenyl)-1,3,4-thiadiazole (2a: $617 \mathrm{mg}, 2.644 \mathrm{mmol}$ ), yield 51\% $(157.7 \mathrm{mg})$; ratio of anomers $(\alpha: \beta=1: 99) ; \alpha^{24} \mathrm{D}=8.6\left(\mathrm{c}=0.35, \mathrm{CHCl}_{3}\right) ;{ }^{1} \mathrm{H} \mathrm{NMR}(400 \mathrm{MHz}$, $\left.\mathrm{CDCl}_{3}\right): \delta 7.60-7.43(\mathrm{~m}, 4 \mathrm{H}, \mathrm{Ph}), 6.01(\mathrm{~d}, J=10.4 \mathrm{~Hz}, 1 \mathrm{H}, \mathrm{H}-1 \beta), 5.51(\mathrm{dd}, J=8.8 \mathrm{~Hz}$, $10.8 \mathrm{~Hz}, 1 \mathrm{H}, \mathrm{H}-4 \beta), 5.14(\mathrm{dd}, J=9.6 \mathrm{~Hz}, 10 \mathrm{~Hz}, 1 \mathrm{H}, \mathrm{H}-3 \beta), 4.73-4.68(\mathrm{~m}, 1 \mathrm{H}, \mathrm{H}-2 \beta), 4.35$ $(\mathrm{dd}, J=4.4 \mathrm{~Hz}, 12.8 \mathrm{~Hz}, 1 \mathrm{H}, \mathrm{H}-6 \beta), 4.15(\mathrm{dd}, J=2.0 \mathrm{~Hz}, 12.4 \mathrm{~Hz}, 1 \mathrm{H}, \mathrm{H}-6 \beta), 4.10-4.06(\mathrm{~m}$, $1 \mathrm{H}, \mathrm{H}-5 \beta), 2.12\left(\mathrm{~s}, 3 \mathrm{H}, \mathrm{COCH}_{3}\right), 2.06\left(\mathrm{~s}, 3 \mathrm{H}, \mathrm{COCH}_{3}\right), 2.04\left(\mathrm{~s}, 3 \mathrm{H}, \mathrm{COCH}_{3}\right), 1.35(\mathrm{~s}, 3 \mathrm{H}$, $\left.\mathrm{C}\left(\mathrm{CH}_{3}\right)_{3}\right), 1.34\left(\mathrm{~s}, 3 \mathrm{H}, \mathrm{C}\left(\mathrm{CH}_{3}\right)_{3}\right)$, and $1.33\left(\mathrm{~s}, 3 \mathrm{H}, \mathrm{C}\left(\mathrm{CH}_{3}\right)_{3}\right) ;{ }^{13} \mathrm{C}$ NMR $\left(150 \mathrm{MHz}, \mathrm{CDCl}_{3}\right)$ : $\delta 170.5\left(\mathrm{COCH}_{3}\right), 170.4\left(\mathrm{COCH}_{3}\right), 170.1\left(\mathrm{COCH}_{3}\right), 169.8\left(\mathrm{COCH}_{3}\right), 165.5(\mathrm{~S}-\mathrm{C}=\mathrm{N}), 156.2$ $\left(\mathrm{C}-\mathrm{C}\left(\mathrm{CH}_{3}\right)_{3}\right), 154.4\left(\mathrm{C}-\mathrm{C}\left(\mathrm{CH}_{3}\right)_{3}\right), 146.2(\mathrm{~S}-\mathrm{C}=\mathrm{N}), 129.3(\mathrm{Ph}), 128.1(\mathrm{Ph}), 127.0(\mathrm{Ph}), 126.8$ (Ph), 98.6 (C-1), 80.2 (C-1), 74.2 (C-3), 73.2 (C-3), 70.5 (C-5), 68.2 (C-5), 63.5 (C-4), 63.2 (C-4), $62.2(\mathrm{C}-6), 60.8(\mathrm{C}-6), 36.1(\mathrm{C}-2), 31.5\left(\mathrm{C}\left(\mathrm{CH}_{3}\right)_{3}\right), 29.6\left(\mathrm{C}^{\left.\left(\mathrm{CH}_{3}\right)_{3}\right)}\right), 27.3(\mathrm{C}-2), 21.9\left(\mathrm{COCH}_{3}\right)$, $21.5\left(\mathrm{COCH}_{3}\right), 20.9\left(\mathrm{COCH}_{3}\right), 20.7\left(\mathrm{COCH}_{3}\right)$, and $20.5\left(\mathrm{COCH}_{3}\right)$; HRMS $\mathrm{m} / z$ calcd for $\left(\mathrm{C}_{24} \mathrm{H}_{30} \mathrm{IN}_{3} \mathrm{O}_{7} \mathrm{~S}+\mathrm{H}^{+}\right): 632.09$ 22; found: 632.0930 .

5-phenyl-N-(3,4,6-tri-O-acetyl-2-deoxy-2-iodo- $\alpha / \beta$-D-glucopyranosyl)-1,3,4-thiadiazol-2-amine (3f): Starting from 3,4,6-tri-O-acetyl-D-glucal (1b: $243 \mathrm{mg}, 0.893 \mathrm{mmol}$ ) and 2-amino-5phenyl-1,3,4-thiadiazole (2b: $316 \mathrm{mg}, 1.783 \mathrm{mmol})$, yield $68 \%(107.8 \mathrm{mg})$; ratio of anomers $(\alpha: \beta=4.4: 1) ;{ }^{1} \mathrm{H}$ NMR $\left(600 \mathrm{MHz}, \mathrm{CDCl}_{3}\right): \delta 7.70-7.68(\mathrm{~m}, 2 \mathrm{H}, \mathrm{Ph}), 7.47-7.44(\mathrm{~m}, 3 \mathrm{H}, \mathrm{Ph})$, $6.30(\mathrm{~d}, J=4.8 \mathrm{~Hz}, 1 \mathrm{H}, \mathrm{H}-1 \beta), 5.94(\mathrm{~d}, J=10.8 \mathrm{~Hz}, 1 \mathrm{H}, \mathrm{H}-1 \alpha), 5.48(\mathrm{dd}, J=9.6 \mathrm{~Hz}, 11.4 \mathrm{~Hz}$, $1 \mathrm{H}, \mathrm{H}-3 \alpha), 5.36(\mathrm{dd}, 1 \mathrm{H}, J=4.2 \mathrm{~Hz}, 6.6 \mathrm{~Hz}, \mathrm{H}-3 \beta), 5.28(\mathrm{t}, J=6.6 \mathrm{~Hz}, 1 \mathrm{H}, \mathrm{H}-4 \beta), 5.15-5.10$ $(\mathrm{m}, 2 \mathrm{H}, \mathrm{H}-4 \alpha, \mathrm{H}-6 \beta), 4.72-4.67$ (m, 1H, H-6 $\alpha), 4.37-4.34(\mathrm{~m}, 2 \mathrm{H}, \mathrm{H}-2 \alpha, \mathrm{H}-6 \beta), 4.29-4.22$ (m, $2 \mathrm{H}, \mathrm{H}-2 \beta, \mathrm{H}-5 \beta), 4.14$ (dd, $J=1.8 \mathrm{~Hz}, 12.6 \mathrm{~Hz} 1 \mathrm{H}, \mathrm{H}-6 \alpha), 4.00$ (m, 1H, H-5 $\alpha), 2.19$ (s, 3H, $\left.\mathrm{COCH}_{3}\right), 2.12\left(\mathrm{~s}, 6 \mathrm{H}, \mathrm{COCH}_{3}\right), 2.09\left(\mathrm{~s}, 3 \mathrm{H}, \mathrm{COCH}_{3}\right)$, and $2.07\left(\mathrm{~s}, 3 \mathrm{H}, \mathrm{COCH}_{3}, 2.05(\mathrm{~s}, 3 \mathrm{H}\right.$, $\left.\mathrm{COCH}_{3}\right) ;{ }^{13} \mathrm{C} \mathrm{NMR}\left(150 \mathrm{MHz}, \mathrm{CDCl}_{3}\right): \delta 170.7\left(\mathrm{COCH}_{3}\right), 169.5\left(\mathrm{COCH}_{3}\right), 169.3\left(\mathrm{COCH}_{3}\right)$, $161.5(\mathrm{~S}-\mathrm{C}=\mathrm{N}), 147.5(\mathrm{~N}-\mathrm{C}=\mathrm{N}), 130.8(\mathrm{Ph}), 129.0(\mathrm{Ph}), 126.2(\mathrm{Ph}), 82.9(\mathrm{C}-1), 72.9(\mathrm{C}-3), 70.8$ (C-5), $67.5(\mathrm{C}-4), 61.6(\mathrm{C}-6), 25.7(\mathrm{C}-2), 21.0\left(\mathrm{COCH}_{3}\right), 20.8\left(\mathrm{COCH}_{3}\right)$, and $20.7\left(\mathrm{COCH}_{3}\right)$; HRMS $m / z$ calcd for $\left(\mathrm{C}_{20} \mathrm{H}_{22} \mathrm{IN}_{3} \mathrm{O}_{7} \mathrm{~S}+\mathrm{H}^{+}\right)$: 576.0296; found: 576.0309 .

5-(4-fluorophenyl)-N-(3,4,6-tri-O-acetyl-2-deoxy-2-iodo- $\alpha / \beta$-D-glucopyranosyl)-1,3,4-thiadiazol2-amine (3g): Starting from 3,4,6-tri-O-acetyl-D-glucal (1b: $304 \mathrm{mg}, 1.117 \mathrm{mmol}$ ) and 2amino-5-(4-fluorophenyl)-1,3,4-thiadiazole (2c: $436 \mathrm{mg}, 2.233 \mathrm{mmol}$ ), yield $58 \%$ (126.4 mg); ratio of anomers $(\alpha: \beta=1: 1.3) ;{ }^{1} \mathrm{H}$ NMR $\left(400 \mathrm{MHz}, \mathrm{CDCl}_{3}\right): \delta 8.15-8.10(\mathrm{~m}, 2 \mathrm{H}, \mathrm{Ph})$, 7.16-7.12 (m, 2H, Ph), $6.27(\mathrm{~d}, J=4.8 \mathrm{~Hz}, 1 \mathrm{H}, \mathrm{H}-1 \alpha), 5.99(\mathrm{~d}, J=10.4 \mathrm{~Hz}, 1 \mathrm{H}, \mathrm{H}-1 \beta), 5.50$ $(\mathrm{dd}, J=9.2 \mathrm{~Hz}, 11.2 \mathrm{~Hz}, 1 \mathrm{H}, \mathrm{H}-3 \beta), 5.33-5.30(\mathrm{~m}, 1 \mathrm{H}, \mathrm{H}-3 \alpha), 5.26(\mathrm{t}, J=6.8 \mathrm{~Hz}, 1 \mathrm{H}, \mathrm{H}-4 \alpha)$, 5.16-5.11 (m, 2H, H-4 $\beta, \mathrm{H}-2 \alpha)$, 4.71-4.66 (m, $1 \mathrm{H}, \mathrm{H}-2 \beta)$, 4.44-4.21 (m, 4H, H-5 $\alpha, \mathrm{H}-6 \mathrm{a} \alpha$, $\mathrm{H}-6 \mathrm{~b} \alpha, \mathrm{H}-6 \mathrm{a} \beta), 4.14(\mathrm{dd}, J=2.0 \mathrm{~Hz}, 14.4 \mathrm{~Hz} 1 \mathrm{H}, \mathrm{H}-6 \mathrm{~b} \beta), 4.07-4.03(\mathrm{~m}, 1 \mathrm{H}, \mathrm{H}-5 \beta), 2.19$ (s, $\left.3 \mathrm{H}, \mathrm{COCH}_{3}\right), 2.12\left(\mathrm{~s}, 3 \mathrm{H}, \mathrm{COCH}_{3}\right), 2.10\left(\mathrm{~s}, 3 \mathrm{H}, \mathrm{COCH}_{3}\right), 2.05\left(\mathrm{~s}, 3 \mathrm{H}, \mathrm{COCH}_{3}\right)$, and 2.04 (s, 3H, $\left.\mathrm{COCH}_{3}\right) ;{ }^{13} \mathrm{C}$ NMR $\left(100 \mathrm{MHz}, \mathrm{CDCl}_{3}\right): \delta 170.6\left(\mathrm{COCH}_{3}\right), 170.0\left(\mathrm{COCH}_{3}\right), 169.6$ $\left(\mathrm{COCH}_{3}\right), 169.5\left(\mathrm{COCH}_{3}\right), 169.3\left(\mathrm{COCH}_{3}\right), 166.2(\mathrm{~d}, \mathrm{~J}=153 \mathrm{~Hz}, \mathrm{C}-\mathrm{F}), 163.0(\mathrm{~S}-\mathrm{C}=\mathrm{N}), 145.6$ 
$(\mathrm{N}-\mathrm{C}=\mathrm{N}), 132.8(\mathrm{Ph}), 132.7(\mathrm{Ph}), 129.0(\mathrm{Ph}), 128.2(\mathrm{Ph}), 116.3(\mathrm{Ph}), 116.1(\mathrm{Ph}), 115.8(\mathrm{Ph})$, 115.5 (Ph), 84.2 (C-1), 83.5 (C-1), 76.1 (C-3), 74.3 (C-3), 73.2 (C-5), 70.6 (C-5), 68.7 (C-4), $67.3(\mathrm{C}-4), 61.8(\mathrm{C}-6), 61.5(\mathrm{C}-6), 25.9(\mathrm{C}-2), 25.4(\mathrm{C}-2), 21.4\left(\mathrm{COCH}_{3}\right), 21.0\left(\mathrm{COCH}_{3}\right), 20.8$ $\left(\mathrm{COCH}_{3}\right), 20.7\left(\mathrm{COCH}_{3}\right)$, and $20.6\left(\mathrm{COCH}_{3}\right) ; \mathrm{HRMS} m / z$ calcd for $\left(\mathrm{C}_{20} \mathrm{H}_{21} \mathrm{FIN}_{3} \mathrm{O}_{7} \mathrm{~S}+\mathrm{H}^{+}\right)$: 594.0202; found: 509.0209 .

5-(4-chlorophenyl)-N-(3,4,6-tri-O-acetyl-2-deoxy-2-iodo- $\beta$-L-glucopyranosyl)-1,3,4-thiadiazol2-amine (3h): Starting from 3,4,6-tri-O-acetyl-D-glucal (1b: 288 mg, $1.058 \mathrm{mmol}$ ) and 2amino-5-(4-chlorophenyl)-1,3,4-thiadiazole (2d: $448 \mathrm{mg}, 2.116 \mathrm{mmol})$, yield 69\% (154.6 mg); ratio of anomers $(\alpha: \beta=1: 99) ; \alpha^{24} \mathrm{D}=177.7\left(\mathrm{c}=0.6, \mathrm{CHCl}_{3}\right) ;{ }^{1} \mathrm{H} \mathrm{NMR}\left(400 \mathrm{MHz}, \mathrm{CDCl}_{3}\right)$ : $\delta$ 7.59-7.56 (m, 2H, Ph), 7.43-7.40 (m, 2H, Ph), 5.94 (d, J = 10.0 Hz, 1H, H-1ß), 5.47 (dd, $J=8.8 \mathrm{~Hz}, 10.8 \mathrm{~Hz}, 1 \mathrm{H}, \mathrm{H}-3 \beta), 5.13(\mathrm{dd}, J=9.2 \mathrm{~Hz}, 10 \mathrm{~Hz}, 1 \mathrm{H}, \mathrm{H}-4 \beta), 4.68-4.62(\mathrm{~m}, 1 \mathrm{H}$, $\mathrm{H}-2 \beta), 4.35(\mathrm{dd}, J=4.4 \mathrm{~Hz}, 12.4 \mathrm{~Hz}, 1 \mathrm{H}, \mathrm{H}-6 \mathrm{a} \beta), 4.14(\mathrm{dd}, J=2.4 \mathrm{~Hz}, 12.8 \mathrm{~Hz} 1 \mathrm{H}, \mathrm{H}-$ $6 \mathrm{~b} \beta), 4.01-3.97(\mathrm{~m}, 1 \mathrm{H}, \mathrm{H}-5 \beta), 2.12\left(\mathrm{~s}, 3 \mathrm{H}, \mathrm{COCH}_{3}\right), 2.07\left(\mathrm{~s}, 3 \mathrm{H}, \mathrm{COCH}_{3}\right)$, and $2.04(\mathrm{~s}, 3 \mathrm{H}$, $\left.\mathrm{COCH}_{3}\right) ;{ }^{13} \mathrm{C} \mathrm{NMR}\left(150 \mathrm{MHz}, \mathrm{CDCl}_{3}\right): \delta 170.6\left(\mathrm{COCH}_{3}\right), 170.5\left(\mathrm{COCH}_{3}\right), 169.8\left(\mathrm{COCH}_{3}\right)$, $169.7\left(\mathrm{COCH}_{3}\right), 169.5\left(\mathrm{COCH}_{3}\right), 156.6(\mathrm{~S}-\mathrm{C}=\mathrm{N}), 146.5(\mathrm{~N}-\mathrm{C}=\mathrm{N}), 139.3(\mathrm{C}-\mathrm{Cl}), 129.8(\mathrm{Ph})$, $129.6(\mathrm{Ph}), 129.1(\mathrm{Ph}), 128.3(\mathrm{Ph}), 127.9(\mathrm{Ph}), 98.7(\mathrm{C}-1), 80.9(\mathrm{C}-1), 78.2(\mathrm{C}-3), 73.5(\mathrm{C}-3)$, 68.2 (C-5), 67.5 (C-5), 64.3 (C-4), 62.5 (C-6), 60.5 (C-6), 29.8 (C-2), 26.7 (C-2), $21.5\left(\mathrm{COCH}_{3}\right)$, $21.3\left(\mathrm{COCH}_{3}\right), 20.9\left(\mathrm{COCH}_{3}\right), 20.7\left(\mathrm{COCH}_{3}\right)$, and $20.6\left(\mathrm{COCH}_{3}\right) ; \mathrm{HRMS} \mathrm{m} / z$ calcd for $\left(\mathrm{C}_{20} \mathrm{H}_{21} \mathrm{ClIN}_{3} \mathrm{O}_{7} \mathrm{~S}+\mathrm{H}^{+}\right)$: 609.9906; found: 609.9917.

5-(4-(tert-buthyl)phenyl)-N-(3,4,6-tri-O-acetyl-2-deoxy-2-iodo- $\alpha / \beta$-D-galactopyranosyl)-1,3,4thiadiazol-2-amine (3i): Starting from 3,4,6-tri-O-acetyl-D-galactal (1c: $163 \mathrm{mg}, 0.599 \mathrm{mmol})$ and 2-amino-5-(4-tert-buthylphenyl)-1,3,4-thiadiazole (2a: $279 \mathrm{mg}, 1.196 \mathrm{mmol}$ ), yield 72\% $(100.7 \mathrm{mg})$; ratio of anomers $(\alpha: \beta=2.3: 1) ;{ }^{1} \mathrm{H} \mathrm{NMR}\left(600 \mathrm{MHz}, \mathrm{CDCl}_{3}\right): \delta 7.80-7.62(\mathrm{~m}, 2 \mathrm{H}$, $\mathrm{Ph}), 7.50-7.46(\mathrm{~m}, 2 \mathrm{H}, \mathrm{Ph}), 6.72(\mathrm{~d}, 1 \mathrm{H}, J=7.8 \mathrm{~Hz}, \mathrm{H}-1 \alpha), 6.55(\mathrm{dd}, 1 \mathrm{H}, J=1.2 \mathrm{~Hz}, 6.0 \mathrm{~Hz}$, $\mathrm{H}-1 \beta), 5.80(\mathrm{t}, 1 \mathrm{H}, J=3.0 \mathrm{~Hz}, \mathrm{H}-4 \beta), 5.55-5.53(\mathrm{~m}, 1 \mathrm{H}, \mathrm{H}-4 \alpha), 5.49(\mathrm{dd}, 1 \mathrm{H}, J=3.6 \mathrm{~Hz}$, $5.4 \mathrm{~Hz}, \mathrm{H}-3 \alpha), 5.42-5.41(\mathrm{~m}, 1 \mathrm{H}, \mathrm{H}-3 \beta), 5.09(\mathrm{dd}, 1 \mathrm{H}, J=3.6 \mathrm{~Hz}, 8.4 \mathrm{~Hz}, \mathrm{H}-2 \alpha), 4.72-4.71$

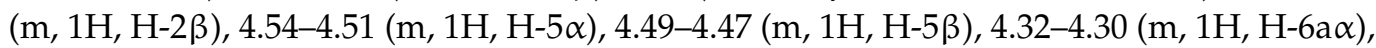
4.27-4.19 (m, 3H, H-6b $\alpha, \mathrm{H}-6 \mathrm{a} \beta, \mathrm{H}-6 \mathrm{~b} \beta$ ), 2.33 (s, 6H, COCH${ }_{3} \alpha, \mathrm{COCH}_{3} \beta$ ), 2.26 (s, 6H, $\left.\mathrm{COCH}_{3} \alpha, \mathrm{COCH}_{3} \beta\right), 2.12\left(\mathrm{~s}, 6 \mathrm{H}, \mathrm{COCH}_{3} \alpha, \mathrm{COCH}_{3} \beta\right), 2.07\left(\mathrm{~s}, 3 \mathrm{H}, \mathrm{COCH}_{3} \alpha\right), 2.02(\mathrm{~s}, 3 \mathrm{H}$, $\left.\mathrm{COCH}_{3} \beta\right), 1.34\left(\mathrm{~s}, 9 \mathrm{H}, \mathrm{C}\left(\mathrm{CH}_{3}\right)_{3}\right)$, and $1.33\left(\mathrm{~s}, 9 \mathrm{H}, \mathrm{C}\left(\mathrm{CH}_{3}\right)_{3}\right) ;{ }^{13} \mathrm{C} \mathrm{NMR}\left(150 \mathrm{MHz}, \mathrm{CDCl}_{3}\right)$ : $\delta 170.6\left(\mathrm{COCH}_{3}\right), 170.3\left(\mathrm{COCH}_{3}\right), 170.2\left(\mathrm{COCH}_{3}\right), 169.5\left(\mathrm{COCH}_{3}\right), 165.7(\mathrm{~S}-\mathrm{C}=\mathrm{N}), 156.4$ $\left(\mathrm{C}-\mathrm{C}\left(\mathrm{CH}_{3}\right)_{3}\right), 155.2\left(\mathrm{C}-\mathrm{C}\left(\mathrm{CH}_{3}\right)_{3}\right), 145.5(\mathrm{~S}-\mathrm{C}=\mathrm{N}), 129.1(\mathrm{Ph}), 128.3(\mathrm{Ph}), 126.7(\mathrm{Ph}), 126.3$ (Ph), 98.9 (C-1), 81.5 (C-1), 73.0 (C-3), 72.9 (C-3), 69.4 (C-5), 66.2 (C-5), 64.0 (C-4), 63.9 (C-4), $62.0(\mathrm{C}-6), 60.3(\mathrm{C}-6), 35.1(\mathrm{C}-2), 31.2\left(\mathrm{C}^{\left.\left(\mathrm{CH}_{3}\right)_{3}\right),}, 29.8\left(\mathrm{C}\left(\mathrm{CH}_{3}\right)_{3}\right), 27.1(\mathrm{C}-2), 21.7\left(\mathrm{COCH}_{3}\right)\right.$, $21.1\left(\mathrm{COCH}_{3}\right), 20.9\left(\mathrm{COCH}_{3}\right), 20.8\left(\mathrm{COCH}_{3}\right)$, and $20.7\left(\mathrm{COCH}_{3}\right) ; \mathrm{HRMS} \mathrm{m} / z$ calcd for $\left(\mathrm{C}_{24} \mathrm{H}_{30} \mathrm{IN}_{3} \mathrm{O}_{7} \mathrm{~S}+\mathrm{H}^{+}\right)$: 632.0922; found: 632.0928 .

5-phenyl-N-(3,4,6-tri-O-acetyl-2-deoxy-2-iodo- $\alpha$-D-galactopyranosyl)-1,3,4-thiadiazol-2-amine (3j): Starting from 3,4,6-tri-O-acetyl-D-galactal (1c: $264 \mathrm{mg}, 0.970 \mathrm{mmol}$ ) and 2-amino-5phenyl-1,3,4-thiadiazole (2b: $344 \mathrm{mg}, 1.941 \mathrm{mmol})$, yield 62\% (106.5 mg); ratio of anomers $(\alpha: \beta=3.8: 1) ;{ }^{1} \mathrm{H}$ NMR $\left(400 \mathrm{MHz}, \mathrm{CDCl}_{3}\right): \delta 7.65-7.63(\mathrm{~m}, 2 \mathrm{H}, \mathrm{Ph}) 7.46-7.42(\mathrm{~m}, 3 \mathrm{H}, \mathrm{Ph}), 6.23$ $(\mathrm{d}, 1 \mathrm{H}, J=8.4 \mathrm{~Hz}, \mathrm{H}-1 \alpha), 5.94(\mathrm{~d}, 1 \mathrm{H}, J=10.8 \mathrm{~Hz}, \mathrm{H}-1 \beta), 5.76(\mathrm{t}, 1 \mathrm{H}, J=3.2 \mathrm{~Hz}, \mathrm{H}-4 \alpha), 5.45$

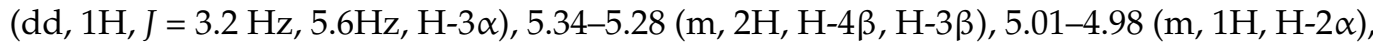
4.73-4.68 (m, 1H, H-6a $\alpha), 4.52-4.47(\mathrm{~m}, 1 \mathrm{H}, \mathrm{H}-5 \alpha), 4.42-4.38(\mathrm{~m}, 1 \mathrm{H}, \mathrm{H}-6 \mathrm{~b} \alpha), 4.27-4.11$ $(\mathrm{m}, 4 \mathrm{H}, \mathrm{H}-2 \beta, \mathrm{H}-5 \beta, \mathrm{H}-6 \mathrm{a} \beta, \mathrm{H}-6 \mathrm{~b} \beta), 2.24$ (s, 3H, $\left.\mathrm{COCH}_{3} \alpha\right), 2.20$ (s, 3H, COCH 3 ), 2.09 $\left(\mathrm{s}, 6 \mathrm{H}, \mathrm{COCH}_{3} \alpha, \mathrm{COCH}_{3} \beta\right), 2.08\left(\mathrm{~s}, 3 \mathrm{H}, \mathrm{COCH}_{3} \alpha\right)$, and $2.04\left(\mathrm{~s}, 3 \mathrm{H}, \mathrm{COCH}_{3} \beta\right) ;{ }^{13} \mathrm{C} \mathrm{NMR}$ $\left(100 \mathrm{MHz}, \mathrm{CDCl}_{3}\right): \delta 169.8\left(\mathrm{COCH}_{3}\right), 169.6\left(\mathrm{COCH}_{3}\right), 169.5\left(\mathrm{COCH}_{3}\right), 162.7(\mathrm{~S}-\mathrm{C}=\mathrm{N}), 147.2$ $(\mathrm{N}-\mathrm{C}=\mathrm{N}), 131.0(\mathrm{Ph}), 129.5(\mathrm{Ph}), 127.5(\mathrm{Ph}), 83.2(\mathrm{C}-1), 73.7(\mathrm{C}-3), 71.3(\mathrm{C}-5), 68.1(\mathrm{C}-4), 62.6$ (C-6), $24.9(\mathrm{C}-2), 21.2\left(\mathrm{COCH}_{3}\right), 20.6\left(\mathrm{COCH}_{3}\right)$, and $20.5\left(\mathrm{COCH}_{3}\right) ; \mathrm{HRMS} m / z$ calcd for $\left(\mathrm{C}_{20} \mathrm{H}_{22} \mathrm{IN}_{3} \mathrm{O}_{7} \mathrm{~S}+\mathrm{H}^{+}\right)$: 576.0296; found: 576.0312 .

5-(4-fluorophenyl)-N-(3,4,6-tri-O-acetyl-2-deoxy-2-iodo- $\alpha / \beta$-D-galactopyranosyl)-1,3,4-thiadiazol2-amine (3k): Starting from 3,4,6-tri-O-acetyl-D-galactal (1c: $213 \mathrm{mg}, 0.782 \mathrm{mmol}$ ) and 2amino-5-(4-fluorophenyl)-1,3,4-thiadiazole (2c: $305 \mathrm{mg}, 1.562 \mathrm{mmol})$, yield 45\% (68.7 mg); ratio of anomers $(\alpha: \beta=4: 1) ;{ }^{1} \mathrm{H}$ NMR $\left(400 \mathrm{MHz}, \mathrm{CDCl}_{3}\right): \delta 7.67-7.6(\mathrm{~m}, 2 \mathrm{H}, \mathrm{Ph}), 7.37-7.36$ $(\mathrm{m}, 2 \mathrm{H}, \mathrm{Ph}), 6.21(\mathrm{~d}, 1 \mathrm{H}, J=8.8 \mathrm{~Hz}, \mathrm{H}-1 \alpha), 5.94(\mathrm{~d}, 1 \mathrm{H}, J=10.4 \mathrm{~Hz}, \mathrm{H}-1 \beta), 5.75(\mathrm{t}, 1 \mathrm{H}$, 
$J=3.2 \mathrm{~Hz}, \mathrm{H}-4 \beta), 5.44(\mathrm{dd}, 1 \mathrm{H}, J=3.2 \mathrm{~Hz}, 5.6 \mathrm{~Hz}, \mathrm{H}-4 \alpha), 5.33-5.28(\mathrm{~m}, 2 \mathrm{H}, \mathrm{H}-3 \beta, \mathrm{H}-3 \alpha), 4.98$ $(\mathrm{dd}, 1 \mathrm{H}, J=3.2 \mathrm{~Hz}, 8.8 \mathrm{~Hz}, \mathrm{H}-2 \alpha), 4.81-4.75(\mathrm{~m}, 2 \mathrm{H}, \mathrm{H}-2 \beta, \mathrm{H}-6 \alpha), 4.51-4.46(\mathrm{~m}, 1 \mathrm{H}, \mathrm{H}-5 \alpha)$, $4.36(\mathrm{dd}, 1 \mathrm{H}, J=3.2 \mathrm{~Hz}, 12.4 \mathrm{~Hz}, 6 \mathrm{~b} \alpha), 4.27-4.12(\mathrm{~m}, 3 \mathrm{H}, \mathrm{H}-5 \beta, \mathrm{H}-6 \mathrm{~b} \beta, \mathrm{H}-6 \mathrm{ab} \beta), 2.24(\mathrm{~s}, 6 \mathrm{H}$, $\left.\mathrm{COCH}_{3} \alpha, \mathrm{COCH}_{3} \beta\right), 2.24\left(\mathrm{~s}, 6 \mathrm{H}, \mathrm{COCH}_{3} \alpha, \mathrm{COCH}_{3} \beta\right), 2.20\left(\mathrm{~s}, 6 \mathrm{H}, \mathrm{COCH}_{3} \alpha, \mathrm{COCH}_{3} \beta\right)$, $2.09\left(\mathrm{~s}, 3 \mathrm{H}, \mathrm{COCH}_{3} \alpha\right)$, and $2.03\left(\mathrm{~s}, 3 \mathrm{H}, \mathrm{COCH}_{3} \beta\right) ; \mathrm{HRMS} \mathrm{m} / z$ calcd for $\left(\mathrm{C}_{20} \mathrm{H}_{21} \mathrm{FIN}_{3} \mathrm{O}_{7} \mathrm{~S}+\right.$ $\left.\mathrm{H}^{+}\right)$: 594.0202; found: 594.0217 .

5-(4-chlorophenyl)-N-(3,4,6-tri-O-acetyl-2-deoxy-2-iodo- $\alpha / \beta$-D-galactopyranosyl)-1,3,4-thiadiazol2-amine (31): Starting from 3,4,6-tri-O-acetyl-D-galactal (1c: $202 \mathrm{mg}, 0.742 \mathrm{mmol}$ ) and 2amino-5-(4-chlorophenyl)-1,3,4-thiadiazole (2d: $314 \mathrm{mg}$, $1.483 \mathrm{mmol}$ ), yield 58\% (90.9 mg); ratio of anomers $(\alpha: \beta=1.4: 1) ;{ }^{1} \mathrm{H}$ NMR $\left(600 \mathrm{MHz}, \mathrm{CDCl}_{3}\right): \delta 7.66-7.63(\mathrm{~m}, 2 \mathrm{H}, \mathrm{Ph})$, 7.45-7.42 (m, 2H, Ph), $6.45(\mathrm{~d}, 1 \mathrm{H}, J=8.4 \mathrm{~Hz}, \mathrm{H}-1 \alpha), 6.23(\mathrm{~d}, 1 \mathrm{H}, J=8.4 \mathrm{~Hz}, \mathrm{H}-1 \beta), 5.74$ $(\mathrm{t}, 1 \mathrm{H}, J=3.0 \mathrm{~Hz}, \mathrm{H}-4 \alpha), 5.55-5.54(\mathrm{~m}, 1 \mathrm{H}, J=3.0 \mathrm{~Hz}, \mathrm{H}-4 \beta), 5.45(\mathrm{dd}, 1 \mathrm{H}, J=3.0 \mathrm{~Hz}, 6.0$ $\mathrm{Hz}, \mathrm{H}-3 \alpha), 5.42-5.41(\mathrm{~m}, 1 \mathrm{H}, \mathrm{H}-3 \beta), 5.00(\mathrm{dd}, 1 \mathrm{H}, J=3.0 \mathrm{~Hz}, 8.4 \mathrm{~Hz}, \mathrm{H}-2 \alpha), 4.73-4.71(\mathrm{~m}$, $1 \mathrm{H}, \mathrm{H}-2 \beta), 4.50-4.47(\mathrm{~m}, 1 \mathrm{H}, \mathrm{H}-5 \alpha), 4.31(\mathrm{t}, 1 \mathrm{H}, J=6.0 \mathrm{~Hz}, \mathrm{H}-6 \mathrm{a} \alpha), 4.28-4.19(\mathrm{~m}, 4 \mathrm{H}, \mathrm{H}-5 \beta$, $\mathrm{H}-6 \mathrm{~b} \alpha, \mathrm{H}-6 \mathrm{a} \beta, \mathrm{H}-6 \mathrm{~b} \beta), 2.26\left(\mathrm{~s}, 3 \mathrm{H}, \mathrm{COCH}_{3} \beta\right), 2.12\left(\mathrm{~s}, 6 \mathrm{H}, \mathrm{COCH}_{3} \alpha, \mathrm{COCH}_{3} \beta\right), 2.08$ (s, $\left.6 \mathrm{H}, \mathrm{COCH}_{3} \alpha, \mathrm{COCH}_{3} \beta\right)$, and $2.02\left(\mathrm{~s}, 3 \mathrm{H}, \mathrm{COCH}_{3} \alpha\right) ;{ }^{13} \mathrm{C} \mathrm{NMR}\left(150 \mathrm{MHz}, \mathrm{CDCl}_{3}\right): \delta 170.6$ $\left(\mathrm{COCH}_{3}\right), 170.4\left(\mathrm{COCH}_{3}\right), 170.2\left(\mathrm{COCH}_{3}\right), 169.4\left(\mathrm{COCH}_{3}\right), 169.3\left(\mathrm{COCH}_{3}\right), 165.6(\mathrm{~S}-\mathrm{C}=\mathrm{N})$, $145.5(\mathrm{~N}-\mathrm{C}=\mathrm{N}), 138.1(\mathrm{C}-\mathrm{Cl}), 129.7(\mathrm{Ph}), 129.5(\mathrm{Ph}), 129.1(\mathrm{Ph}), 128.0(\mathrm{Ph}), 127.6(\mathrm{Ph}), 99.0$ (C-1), 80.5 (C-1), 74.1 (C-3), 72.9 (C-3), 69.7 (C-5), 66.2 (C-5), 64.0 (C-4), 62.0 (C-6), 60.2 (C-6), $29.8(\mathrm{C}-2), 25.7(\mathrm{C}-2), 21.2\left(\mathrm{COCH}_{3}\right), 21.1\left(\mathrm{COCH}_{3}\right), 20.9\left(\mathrm{COCH}_{3}\right), 20.8\left(\mathrm{COCH}_{3}\right)$, and 20.7 $\left(\mathrm{COCH}_{3}\right)$; HRMS $m / z$ calcd for $\left(\mathrm{C}_{20} \mathrm{H}_{21} \mathrm{ClIN}_{3} \mathrm{O}_{7} \mathrm{~S}+\mathrm{H}^{+}\right)$: 609.9906; found: 609.9917.

5-phenyl-N-(3,4-di-O-benzyl-2-deoxy-2-iodo- $\alpha / \beta$-L-rhamnopyranosyl)-1,3,4-thiadiazol-2-amine (3m): Starting from 3,4-di-O-benzyl-L-rhamnal (1d: $131 \mathrm{mg}, 0.442 \mathrm{mmol}$ ) and 2-amino-5-(4tert-buthylphenyl)-1,3,4-thiadiazole (2a: $197 \mathrm{mg}, 0.844 \mathrm{mmol}$ ), yield $42 \%$ yield $(41.5 \mathrm{mg}$ ); ratio of anomers $(\alpha: \beta=1: 1) ;{ }^{1} \mathrm{H} \mathrm{NMR}\left(400 \mathrm{MHz}, \mathrm{CDCl}_{3}\right): \delta 7.70-7.68(\mathrm{~m}, 2 \mathrm{H}, \mathrm{Ph}), 7.47-7.42$ $(\mathrm{m}, 6 \mathrm{H}, \mathrm{Ph}), 7.37-7.31(\mathrm{~m}, 20 \mathrm{H}, \mathrm{Ph}), 5.99(\mathrm{~d}, 1 \mathrm{H}, J=10.2 \mathrm{~Hz}, \mathrm{H}-1), 5.08(\mathrm{dd}, 2 \mathrm{H}, J=2.4 \mathrm{~Hz}$, $\left.10.2 \mathrm{~Hz},-\mathrm{CH}_{2}-\mathrm{Ph}\right), 4.93-4.88\left(\mathrm{~m}, 4 \mathrm{H},-\mathrm{CH}_{2}-\mathrm{Ph}\right), 4.72-4.66\left(\mathrm{~m}, 3 \mathrm{H}, \mathrm{H}-2,-\mathrm{CH}_{2}-\mathrm{Ph}\right), 4.62(\mathrm{~d}$, $1 \mathrm{H}, \mathrm{J}=9.6 \mathrm{~Hz}, \mathrm{H}-1 \beta), 4.21(\mathrm{t}, 1 \mathrm{H}, J=10.2 \mathrm{~Hz}, \mathrm{H}-2 \beta), 3.90(\mathrm{t}, 1 \mathrm{H}, J=9.6 \mathrm{~Hz}, \mathrm{H}-3), 3.82(\mathrm{dd}$, $1 \mathrm{H}, J=9.0 \mathrm{~Hz}, 10.8 \mathrm{~Hz}, \mathrm{H}-3), 3.72(\mathrm{~m}, 1 \mathrm{H}, \mathrm{H}-5), 3.62(\mathrm{dq}, 1 \mathrm{H}, J=6.6 / 6.0 \mathrm{~Hz}, 9.6 \mathrm{~Hz}, \mathrm{H}-5)$, $3.33(\mathrm{dt}, 2 \mathrm{H}, J=9.0 \mathrm{~Hz}, 14.4 \mathrm{~Hz}, \mathrm{H}-4), 1.37\left(\mathrm{~d}, 3 \mathrm{H}, J=6.6 \mathrm{~Hz}, \mathrm{CH}_{3}\right)$, and $1.33(\mathrm{~d}, 3 \mathrm{H}, J=6 \mathrm{~Hz}$, $\left.\mathrm{CH}_{3}\right) ;{ }^{13} \mathrm{C}$ NMR $\left(100 \mathrm{MHz}, \mathrm{CDCl}_{3}\right): \delta 160.8(\mathrm{~S}-\mathrm{C}=\mathrm{N}), 148.5(\mathrm{~N}-\mathrm{C}=\mathrm{N}), 138.1(\mathrm{Ph}), 138.0(\mathrm{Ph})$, $130.7(\mathrm{Ph}), 130.5(\mathrm{Ph}), 129.0(\mathrm{Ph}), 128.7(\mathrm{Ph}), 128.6(\mathrm{Ph}), 128.5(\mathrm{Ph}), 128.3(\mathrm{Ph}), 128.1(\mathrm{Ph})$, $126.5(\mathrm{Ph}), 95.5$ (C-1), 94.9 (C-1), 86.4 (C-3), 85.1 (C-3), 85.0 (C-4), 75.5 (C-5), $74.3\left(-\mathrm{CH}_{2}\right)^{-}$, $73.9\left(-\mathrm{CH}_{2}-\right)$, $37.6(\mathrm{C}-2), 31.1(\mathrm{C}-2)$, and $17.9(\mathrm{C}-6)$; HRMS $m / z$ calcd for $\left(\mathrm{C}_{28} \mathrm{H}_{28} \mathrm{IN}_{3} \mathrm{O}_{3} \mathrm{~S}+\right.$ $\left.\mathrm{H}^{+}\right)$: 614.0969; found: 614.0969 .

\subsection{Biological Evaluation}

\subsubsection{Cell Lines and Culture Conditions}

Cytotoxicity of drugs was determined for several cell lines. Experiments were performed on HeLa (cervical cancer cell line), HCT 116 (colorectal carcinoma cell line), and MCF-7 (human breast adenocarcinoma cell line) according to the standard procedures described previously [62]. The cells were obtained from American Type Culture Collection (ATCC, Manassas, VA, USA). The culture was performed in Dulbecco's Modified Eagle Medium, Nutrient Mixture F-12 (DMEM/F12, Sigma-Aldrich, Taufkirchen, Germany) supplemented with fetal bovine serum (FBS, Gibco) as a source of growth factors and gentamicin $(40 \mathrm{mg} / \mathrm{mL}$, Krka Poland Sp. z o.o., Warsaw, Poland) in standard quantities. The culture medium for all cell lines contained $12 \%$ of heat-inactivated FBS. Monolayer cell cultures have grown in $75 \mathrm{~cm}^{2}$ surface bottles (Nunc, ThermoFisher, Waltham, MA, USA), in an incubator (Heracell 150i TM, Thermo Scientific ${ }^{\mathrm{TM}}$, Merck, Darmstadt, Germany) of a solid concentration of $5 \%$ carbon dioxide, $37^{\circ} \mathrm{C}$, and constant humidity of $80 \%$. The culture was maintained in vitro by the passaging of cells (every 3 to 4 days). For the experiments, cells were obtained by trypsinization with $0.25 \%$ trypsin solution (Trypsin EDTA, Immuniq, Żory, Poland) in phosphate-buffered saline lacking $\mathrm{Ca}^{+2}$ and $\mathrm{Mg}^{+2}$ (PBS) to detach them from the ground. Trypsin was neutralized by adding an equal amount of the culture 
medium. After centrifugation (1500 rpm, $5 \mathrm{~min}$.), the cells were resuspended in a fresh culture medium and counted using an automatic cell counter-Juli Stage (NanoEntek, Waltham, MA, USA).

\subsubsection{Cytotoxicity Test by MTT Assay}

For the cytotoxicity determination of the tested derivatives, the cells in the exponential growth phase were trypsinized and seeded on 96-well plates (Nunc, ThermoFisher, Waltham, MA, USA) at concentration $5 \times 10^{4}$ cells/well/200 $\mu \mathrm{L}$ in completed grown medium. After approx. $24 \mathrm{~h}$ the culture medium was replaced with a fresh culture medium containing serial dilutions of the tested drugs. After $72 \mathrm{~h}$, a solution of the compound was removed. Next, cell viability was determined by the MTT assay based on mitochondrial dehydrogenase enzyme activity. The basis of the method is the reaction of the reduction of tetrazolium salts to colored formazan carried out by dehydrogenase in living cells. Therefore, the amount of formazan formed is proportional to the number of functional cells. MTT assay was carried out according to the protocol (MTT, Sigma-Adrich, Taufkirchen, Germany) $[63,64]$. To each well on the plate, $50 \mu \mathrm{L}$ of MTT solution $(0.05 \mathrm{mg} / \mathrm{mL}$ in phenol red and FBS free DMEM-F12; PAA) was added. The plates were then placed in a $\mathrm{CO}_{2}$ incubator for 1 to $2 \mathrm{~h}$. After this time, MTT solution was removed, and formazan crystals were dissolved in acidic isopropanol. Next, spectrophotometrically absorbance measuring at $570 \mathrm{~nm}$, using a multi-well plate reader SYNERGY4 (BioTek Instruments, Winooski, VT, USA) was performed. The fraction of viable cells was determined with concern to not treat with any factor control cells, according to the following formula:

$$
\mathrm{SF}=\frac{\mathrm{A}}{\mathrm{A}_{\mathrm{K}}} \times 100 \%
$$

SF-survival fraction;

A-the absorbance value;

$A_{K}$ - the absorbance value for control cells.

\subsubsection{Cell Cycle and Apoptosis Analysis}

The exponentially growing cells were harvested by trypsinization and seeded on a 6-well plate (Nunc, ThermoFisher, Waltham, MA, USA) in DMEM/F12 medium at concentrations of $1 \times 10^{5}$ cells $/$ well $/ 2 \mathrm{~mL}$. After $72 \mathrm{~h}$, the growth medium was exchanged for a fresh medium in control groups or medium containing the tested drugs at chosen concentrations. The cells were incubated for $72 \mathrm{~h}$. After this time, the medium was collected and the cells were trypsinized with $1 \mathrm{~mL}$ trypsin/EDTA (Sigma-Aldrich, Taufkirchen, Germany). Trypsin was then neutralized by adding $2 \mathrm{~mL}$ of culture medium. The cells were centrifuged at $1300 \mathrm{rpm}$ for $5 \mathrm{~min}$ at $4{ }^{\circ} \mathrm{C}$, washed twice with $1 \mathrm{~mL}$ PBS, and finally fixed with $1 \mathrm{~mL}$ of ice-cold $70 \%$ ethanol. The samples were stored at $-20^{\circ} \mathrm{C}$ until analysis. Directly before the analysis by flow cytometer (Becton Dickinson Aria III, BD Company, San Diego, CA, USA), cells were centrifuged at $1300 \mathrm{rpm}$ for $3 \mathrm{~min}$, washed with $500 \mu \mathrm{L}$ PBS, and centrifuged again. Then, cells were resuspended in $50 \mu \mathrm{L}$ PBS and $50 \mu \mathrm{L}$ of RNAse solution (Sigma-Aldrich, Taufkirchen, Germany) at a concentration of $100 \mu \mathrm{g} / \mathrm{mL}$ (in PBS). After $15 \mathrm{~min}$ of incubation at $37^{\circ} \mathrm{C}$, cells were stained with $250 \mu \mathrm{L}$ propidium iodide solution (PI, Sigma-Aldrich, Taufkirchen, Germany) at a concentration of $100 \mu \mathrm{g} / \mathrm{mL}$. Fluorescence was measured using a flow cytometer with the PE configuration (547 nm excitation laser line; emission: $585 \mathrm{~nm}$ ). The samples were vortexed before analysis [65,66].

For apoptosis assay, the cells after collection were stained directly using FITC conjugated primary Annexin-V antibody (BioLegend, San Diego, USA) in binding buffer for $20 \mathrm{~min}$ in darkness at $37^{\circ} \mathrm{C}$ and Annexin with PI solution $100 \mu \mathrm{g} / \mathrm{mL}$ (Sigma-Aldrich, Taufkirchen, Germany). Fluorescence was measured using a flow cytometer with the PE configuration ( $547 \mathrm{~nm}$ excitation laser line; emission: $585 \mathrm{~nm}$ ) for necrotic and late apoptotic cell counting. For apoptotic cells, the FITC channel configuration was used (488 nm 
excitation laser line; emission: LP mirror 503, BP filter 530/30). The samples were vortexed before analysis $[65,66]$.

\subsubsection{Statistical Analysis}

At least three replicates were performed for every kind of experiment. The results were presented as the mean value \pm SD. The statistical analysis was based on a t-test, and a $p$-value less than 0.05 was considered statistically significant.

Supplementary Materials: The Supporting Information is available online. ${ }^{1} \mathrm{H}$ and ${ }^{13} \mathrm{C}$ NMR spectra of all obtained compounds, Figure S1: Typical histograms of PI stained DNA content during the cell cycle of MCF-7, HCT116, and HeLa cells, after $72 \mathrm{~h}$ of incubation with compounds at a dose of $100 \mu \mathrm{M}$; Figure S2:Typical dot plots of normal, early apoptotic, late apoptotic and necrotic MCF-7, HCT116, and HeLa cells after $72 \mathrm{~h}$ of incubation with compounds at a dose of $100 \mu \mathrm{M}$; General procedure for the synthesis of 2-benzoylhydrazinecarbothioamide derivatives (6).

Author Contributions: Conceptualization, methodology, and planning of the experiments, K.Ż. and A.K. (Anna Kasprzycka); synthesis of chemical compounds, K.Ż., M.S. (Marcin Stokowy), P.K., M.O. and A.K. (Agnieszka Kudelko); characterization of chemical compounds, K.Ż.; performing cytotoxicity tests, M.S. (Magdalena Skonieczna); analysis and interpretation of the results, K.Ż., K.P. and A.K. (Anna Kasprzycka); writing original draft preparation, K.Ż.; review and editing of the manuscript, A.K. (Anna Kasprzycka); helped in editing of the manuscript, W.S. and K.W. All authors have read and agreed to the published version of the manuscript.

Funding: This research was funded by Grant BKM No. 04/020/BKM18/0074 (BKM-525/RCH2/2018) as part of a targeted subsidy for conducting scientific research or development works and related tasks for the development of young scientists and participants of doctoral studies granted by the Ministry of Science and Higher Education, Poland. Research supported by the Silesian University of Technology's own scholarship fund in the field of research and development, year 2019, grant no. 05/FSW18/0003-05/2019 (A. Kasprzycka)).

Institutional Review Board Statement: Not applicable.

Informed Consent Statement: Not applicable.

Data Availability Statement: Data is contained within the article or supplementary material.

Acknowledgments: We would like to thank Karol Erfurt for HRMS experiments.

Conflicts of Interest: The authors declare no conflict of interest.

Sample Availability: Samples of the compounds 3a-3m are available from the authors.

\section{References}

1. Othman, A.A.; Kihel, M.; Amara, S. 1,3,4-Oxadiazole, 1,3,4-thiadiazole and 1,2,4-triazole derivatives as potential antibacterial agents. Arab. J. Chem. 2019, 12, 1660-1675. [CrossRef]

2. Yan, M.; Xu, L.; Wang, Y.; Wan, J.; Liu, T.; Liu, W.; Wan, Y.; Zhang, B.; Wang, R.; Lim, Q. Opportunities and challenges of using five-membered ring compounds as promising antitubercular agents. Drug Dev. Res. 2020, 81, 402-418. [CrossRef]

3. Asif, M.; Abida. A mini review on thiadiazole compounds and their pharmacological interest. Int. J. Pharm. Chem. Anal. 2018, 5, 156-164. [CrossRef]

4. Serban, G. Synthetic Compounds with 2-Amino-1,3,4-Thiadiazole Moiety Against Viral Infections. Molecules 2020, 25, 942. [CrossRef] [PubMed]

5. Ahadi, H.; Shokrzadeh, M.; Hosseini-khah, Z.; Ghassemi barghi, N.; Ghasemian, M.; Emadi, E.; Zargari, M.; Razzaghi-Asl, N.; Emami, S. Synthesis and biological assessment of ciprofloxacin-derived 1,3,4-thiadiazoles as anticancer agents. Bioorg. Chem. 2020, 105, 104383. [CrossRef] [PubMed]

6. Szeliga, M. Thiadiazole derivatives as anticancer agents. Pharmacol. Rep. 2020, 72, 1079-1100. [CrossRef]

7. Farahat, A.; Tawfik, S.S.; Liu, M. Antiviral activity of thiadiazoles, oxadiazoles, triazoles and thiazoles. ARKIVOC 2020, part i, 180-210. [CrossRef]

8. Hu, Y.; Li, C.Y.; Wang, X.M.; Yang, Y.H.; Zhu, H.L. 1,3,4-Thiadiazole: Synthesis, Reactions, and Applications in Medicinal, Agricultural, and Materials Chemistry. Chem. Rev. 2014, 114, 5572-5610. [CrossRef]

9. Zong, G.; Zhao, H.; Jiang, R.; Zhang, J.; Liang, S.; Li, B.; Shi, Y.; Wang, D. Design, Synthesis and Bioactivity of Novel Glycosylthiadiazole Derivatives. Molecules 2014, 19, 7832-7849. [CrossRef] 
10. Nath, M.; Sulaxna; Song, X.; Eng, G. Synthesis, spectral and thermal studies of some organotin(IV) derivatives of 5-amino-3H1,3,4-thiadiazole-2-thione. Spectrochimica Acta Part A 2006, 64, 148-155. [CrossRef] [PubMed]

11. Fahlisch, B.; Braun, R.; Schultz, K.W. A SimpIe Synthesis of 1,3,4-Thiadiazole. Angew. Chem. Intern. Edit. 1967, 6, 361-362. [CrossRef]

12. Janowska, S.; Paneth, A.; Wujec, M. Cytotoxic Properties of 1,3,4-Thiadiazole Derivatives-A Review. Molecules 2020, 25, 4309. [CrossRef]

13. Flefel, E.M.; El-Sayed, W.A.; Mohamed, A.M.; El-Sofany, W.I.; Awad, H.M. Synthesis and Anticancer Activity of New 1-Thia-4azaspiro[4.5]decane, Their Derived Thiazolopyrimidine and 1,3,4-Thiadiazole Thioglycosides. Molecules 2017, 22, 170. [CrossRef]

14. Haider, S.; Alam, M.S.; Hamid, H. 1,3,4-Thiadiazoles: A potent multi targeted pharmacological scaffold. Eur. J. Med. Chem. 2015, 92, 156-177. [CrossRef] [PubMed]

15. Horton, D.; Priebe, W.; Varela, O. Synthesis and antitumor activity of 2'-bromo- and 2'-chloro-3'-acetoxy-3'-deaminodaunorubicin analogs. Carbohydr. Res. 1985, 144, 305-315. [CrossRef]

16. Horton, D.; Priebe, W.; Varela, O. Halogenation of 1,5-anhydrohex-1-enitols (glycals). Influence of the C-6 substituent. J. Org. Chem. 1986, 51, 3479-3485. [CrossRef]

17. Horton, D.; Priebe, W.; Sznaidman, M. Iodoalkoxylation of 1,5-anhydro-2-deoxy-hex-1-enitols (glycals). Carbohydr. Res. 1990, 205, 71-86. [CrossRef]

18. Vudhgiri, S.; Koude, D.; Veeragoni, D.K.; Misra, S.; Prasad, R.B.N.; Jala, R.C.R. Synthesis and biological evaluation of 5-fattyacylamido-1, 3, 4-thiadiazole-2-thioglycosides. Bioorg. Med. Chem. Lett. 2017, 27, 3370-3373. [CrossRef] [PubMed]

19. Bhatia, R.; Sharma, A.; Kaundal, A. A Review on 1,3,4-Thiadiazole Derivatives. Indian J. Pharm. Sci. $2014,4,165-172$.

20. EL-Naggar, S.A.; El-Barbary, A.A.; Mansour, M.A.; Abdel-Shafy, F.; Talat, S. Anti-tumor Activity od Some 1,3,4-thiadiazoles and 1,2,4-triazune Derivatives against Ehrlichs Ascites Carcinoma. Int. J. Cancer Res. 2011, 7, 278-288. [CrossRef]

21. Ibrahim, D.A. Synthesis and biological evaluation of 3,6-disubstituted $[1,2,4]$ triazolo[3,4-b][1,3,4]thiadiazole derivatives as a novel class of potential anti-tumor agents. Eur. J. Med. Chem. 2009, 44, 2776-2781. [CrossRef] [PubMed]

22. Karki, S.S.; Panjamurthy, K.; Kumar, S.; Nambiar, M.; Ramareddy, S.A.; Chiruvella, K.K.; Raghavan, S.C. Synthesis and biological evaluation of novel 2-aralkyl-5-substituted-6-(4'-fluorophenyl)-imidazo[2,1-b][1,3,4] thiadiazole derivatives as potent anticancer agents. Eur. J. Med. Chem. 2011, 46, 2109-2116. [CrossRef] [PubMed]

23. Kumar, D.; Kumar, N.M.; Chang, K.H.; Shah, K. Synthesis and anticancer activity of 5-(3-indolyl)-1,3,4-thiadiazoles. Eur. J. Med. Chem. 2010, 45, 4664-4668. [CrossRef]

24. Noolvi, M.N.; Patel, H.M.; Singh, N.; Gadad, A.K.; Cameotra, S.S.; Badiger, A. Synthesis and anticancer evaluation of novel 2-cyclopropylimidazo[2,1-b][1,3,4]-thiadiazole derivatives. Eur. J. Med. Chem. 2011, 46, 4411-4418. [CrossRef]

25. Rajak, H.; Agarawal, A.; Parmar, P.; Thakur, B.S.; Veerasamy, R.; Sharma, P.C.; Kharya, M.D. 2,5-Disubstituted-1,3,4oxadiazoles/thiadiazole as surface recognition moiety: Design and synthesis of novel hydroxamic acid based histone deacetylase inhibitors. Bioorganic Med. Chem. Lett. 2011, 21, 5735-5738. [CrossRef]

26. Rzeski, W.; Matysiak, J.; Kandefer-Szerszeń, M. Anticancer, neuroprotective activities and computational studies of 2-amino-1,3,4thiadiazole based compound. Bioorganic Med. Chem. 2007, 15, 3201-3207. [CrossRef] [PubMed]

27. Terzioglu, N.; Gürsoy, A. Synthesis and anticancer evaluation of some new hydrazone derivatives of 2,6-dimethylimidazo[2,1b][1,3,4]thiadiazole-5-carbohydrazide. Eur. J. Med. Chem. 2003, 38, 781-786. [CrossRef]

28. Yang, X.H.; Wen, Q.; Zhao, T.T.; Sun, J.; Li, X.; Xing, M.; Lu, X.; Zhu, H.L. Synthesis, biological evaluation, and molecular docking studies of cinnamic acyl 1,3,4-thiadiazole amide derivatives as novel antitubulin agents. Bioorganic Med. Chem. 2012, 20, 1181-1187. [CrossRef]

29. Calvaresia, E.C.; Hergenrother, P.J. Glucose conjugation for the specific targeting and treatment of cancer. Chem. Sci. 2013, 4, 2319-2333. [CrossRef]

30. Priebe, W.; Szymanski, S.; Fokt, I.; Conrad, C.; Madden, T. Iodo-Hexose Compounds Useful to Treat Cancer. U.S. Patent No.: US 8,299,033, 2010.

31. Gammon, D.W.; Sels, B.F. Other Methods for Glycoside Synthesis: Dehydro and Anhydro Derivatives. In Handbook of Chemical Glycosylation: Advances in Stereoselectivity and Therapeutic Relevance; Demchenko, A.A., Ed.; WILEY-VCH Verlag GmbH \& Co. KGaA: Weinheim, Germany, 2008; pp. 416-448.

32. Veyrières, A. Special Problems in Glycosylation Reactions: 2-Deoxy Sugars. In Carbohydrates in Chemistry and Biology; Ernst, B., Hart, G.W., Sinaý, P., Eds.; WILEY-VCH Verlag GmbH \& Co. KGaA: Weinheim, Germany, 2000; pp. 367-405.

33. Marzabadi, C.H.; Franck, R.W. The Synthesis of 2-Deoxyglycosides: 1988-1999. Tetrahedron 2000, 56, 8385-8417. [CrossRef]

34. Hou, D.; Lowary, T.L. Recent advances in the synthesis of 2-deoxy-glycosides. Carbohydr. Res. 2009, 344, 1911-1940. [CrossRef]

35. Bennett, C.S.; Galan, M.C. Methods for 2-Deoxyglycoside Synthesis. Chem. Rev. 2018, 118, 7931-7985. [CrossRef]

36. Fokt, I.; Szymanski, S.; Skora, S.; Cybulski, M.; Madden, T.; Priebe, W. d-Glucose- and d-mannose-based antimetabolites. Part 2. Facile synthesis of 2-deoxy-2-halo-d-glucoses and -d-mannoses. Carbohydr. Res. 2009, 344, 1464-1473. [CrossRef]

37. Kudelko, A.; Olesiejuk, M.; Luczynski, M.; Swiatkowski, M.; Sieranski, T.; Kruszynski, R. 1,3,4-Thiadiazole-Containing Azo Dyes: Synthesis, Spectroscopic Properties and Molecular Structure. Molecules 2020, 25, 2822. [CrossRef]

38. Rae, D.R.; Belmont, P. Silver(I) Imidazolate. In Encyclopedia of Reagents for Organic Synthesis; John Wiley\&Sons Ltd: New York, NY, USA, 2013. [CrossRef]

39. Thiem, J.; Karl, H.; Schweitner, J. Synthese $\alpha$-verknüpfter 2'-Deoxy-2'-iododisaccharide. Synthesis 1978, 9, 696-698. [CrossRef] 
40. Lemieux, R.U.; Fraser-Reid, B. The Mechanisms of the Halogenations and Halogenomethoxylations of D-Glucal Triacetate, D-Galactal Triacetate, and 3,4-Dihydropyran. Can. J. Chem. 1965, 45, 1460-1475. [CrossRef]

41. Igarashi, K.; Honma, T.; Imagawa, T. Addition reactions of glycals. V. Solvent effects in the chlorine addition to D-glucal triacetate. J. Org. Chem. 1970, 35, 610-616. [CrossRef]

42. Boullanger, P.; Descotes, G. Additions comparées des halogenès sur le 3,4,6-tri-O-acétyl-1,5-anhydro-1,5-didésoxy-, d-arabino-hex1-énitol et l'analogue 3,4,6-tri-O-benzylé; effets de solvant sur la formation spécifique des dérivés 1,2-didésoxy-1,2-dihalogéno- $\alpha$ d-glucopyranoses. Carbohydr. Res. 1976, 51, 55-63. [CrossRef]

43. Thiem, J.; Klaffke, W. Syntheses of deoxy oligosaccharides. Top. Curr. Chem. 1990, 154, 285-332. [CrossRef]

44. Nowacki, A.; Walczak, D.; Liberek, B. Fully acetylated 1,5-anhydro-2-deoxypent-1-enitols and 1,5-anhydro-2,6-dideoxyhex-1enitols in DFT level theory conformational studies. Carbohydr. Res. 2012, 352, 177-185. [CrossRef]

45. Danishefsky, S.J.; Bilodeau, M.T. Glycals in Organic Synthesis: The Evolution of Comprehensive Strategies for the Assembly of Oligosaccharides and Glycoconjugates of Biological Consequence. Angew. Chem. Int. Ed. 1996, 35, 1380-1419. [CrossRef]

46. Dudkin, V.Y.; Miller, J.S.; Danishefsky, S.J. Chemical Synthesis of Normal and Transformed PSA Glycopeptides. J. Am. Chem. Soc. 2004, 126, 736-738. [CrossRef]

47. Geng, X.; Dudkin, V.Y.; Mandal, M.; Danishefsky, S.J. In Pursuit of Carbohydrate-Based HIV Vaccines, Part 2: The Total Synthesis of High-Mannose-Type gp120 Fragments-Evaluation of Strategies Directed to Maximal Convergence. Angew. Chem. Int. Ed. 2004, 43, 2562-2565. [CrossRef] [PubMed]

48. Deshpande, P.P.; Kim, H.M.; Zatorski, A.; Park, T.K.; Ragupathi, G.; Livingston, P.O.; Live, D.; Danishefsky, S.J. Strategy in Oligosaccharide Synthesis: An Application to a Concise Total Synthesis of the KH-1(adenocarcinoma) Antigen. J. Am. Chem. Soc. 1998, 120, 1600-1614. [CrossRef]

49. Kwon, O.; Danishefsky, S.J. Synthesis of Asialo GM1. New Insights in the Application of Sulfonamidoglycosylation in Oligosaccharide Assembly: Subtle Proximity Effects in the Stereochemical Governance of Glycosidation. J. Am. Chem. Soc. 1998, 120, 1588-1599. [CrossRef]

50. Roberge, J.Y.; Beebe, X.; Danishefsky, S.J. Convergent Synthesis of N-Linked Glycopeptides on a Solid Support. J. Am. Chem. Soc. 1998, 120, 3915-3927. [CrossRef]

51. Wang, Z.G.; Warren, J.D.; Dudkin, V.Y.; Zhang, X.; Iserloh, U.; Visser, M.; Eckhardt, M.; Seeberger, P.H.; Danishefsky, S.J. A highly convergent synthesis of an N-linked glycopeptide presenting the H-type 2 human blood group determinant. Tetrahedron 2006, 62, 4954-4978. [CrossRef]

52. Nagorny, P.; Fasching, B.; Li, X.; Chen, G.; Aussedat, B.; Danishefsky, S.J. Toward Fully Synthetic Homogeneous $\beta$-Human Follicle-Stimulating Hormone $(\beta-\mathrm{hFSH})$ with a Biantennary N-Linked Dodecasaccharide. Synthesis of $\beta$-hFSH with Chitobiose Units at the Natural Linkage Sites. J. Am. Chem. Soc. 2009, 131, 5792-5799. [CrossRef]

53. Liu, M.; Young, V.G., Jr.; Lohani, S.; Live, D.; Barany, G. Syntheses of TN building blocks N $\alpha$-(9-fluorenylmethoxycarbonyl)-O(3,4,6-tri-O-acetyl-2-azido-2-deoxy- $\alpha$-d-galactopyranosyl)-1-serine/1-threonine pentafluorophenyl esters: Comparison of protocols and elucidation of side reactions. Carbohydr. Res. 2005, 340, 1273-1285. [CrossRef] [PubMed]

54. Lafont, D.; Descotes, G. Synthèse de phosphoramidates de 2-désoxy-2-iodoglycosyles. Carbohydr. Res. 1987, 166, 195-209. [CrossRef]

55. Gammon, D.W.; Kinfe, H.H.; De Vos, D.E.; Jacobs, P.A.; Sels, B.F. A simple, efficient alternative for highly stereoselective iodoacetoxylation of protected glycals. Tetrahedron Lett. 2004, 45, 9533-9536. [CrossRef]

56. Bellucci, G.; Chiappe, C.; D'Andrea, F.; Lo Moro, G. Stereoelectronic control in two-step additions to tri-O-benzyl-d-glucal initiated by electrophilic halogens. Tetrahedron 1997, 53, 3417-3424. [CrossRef]

57. Boschi, A.; Chiappe, C.; De Rubertis, A.; Ruasse, M.F. Substituent Dependence of the Diastereofacial Selectivity in Iodination and Bromination of Glycals and Related Cyclic Enol Ethers. J. Org. Chem. 2000, 65, 8470-8477. [CrossRef] [PubMed]

58. Lemieux, R.U.; Hendriks, K.B.; Stick, R.V.; James, K. Halide ion catalyzed glycosidation reactions. Syntheses of.alpha.-linked disaccharides. J. Am. Chem. Soc. 1975, 97, 4056-4062.

59. van Well, R.M.; Ravindranathan Kartha, K.P.; Field, R.A. Iodine Promoted Glycosylation with Glycosyl Iodides: $\alpha$-Glycoside Synthesis. J. Carbohydr. Chem. 2005, 24, 463-474. [CrossRef]

60. Priebe, W.; Grynkiewicz, G. Formation and Reactions of Glycal Derivatives. In Glycoscience: Chemistry and Chemical Biology I-III; Fraser-Reid, B.O., Tatsuta, K., Thiem, J., Eds.; Springer: Berlin, Germany, 2001; pp. 749-783.

61. Gervay, J. Glycosyl Iodides in Organic Chemistry. In Organic Synthesis: Theory and Applications; JAI Press Monograph Series; JAI Press: Greenwich, CT, USA, 1998; Volume 4, pp. 121-153.

62. Meloncelli, P.J.; Martin, A.D.; Lowary, T.L. Glycosyl iodides. History and recent Advances. Carbohydr. Res. 2009, 344, 1110-1122. [CrossRef]

63. Byczek-Wyrostek, A.; Kitel, R.; Rumak, K.; Skonieczna, M.; Kasprzycka, A.; Walczak, W. Simple 2(5H)-furanone derivatives with selective cytotoxicity towards non-small cell lung cancer cell line A549-Synthesis, structure-activity relationship and biological evaluation. Eur. J. Med. Chem. 2018, 150, 687-697. [CrossRef]

64. Mielanczyk, A.; Mrowiec, K.; Kupczak, M.; Mielanczyk, Ł.; Scieglinska, D.; Gogler-Piglowska, A.; Michalski, M.; Gabriel, A.; Neugebauer, D.; Skonieczna, M. Synthesis and in vitro cytotoxicity evaluation of star-shaped polymethacrylic conjugates with methotrexate or acitretin as potential antipsoriatic prodrugs. Eur. J. Pharmacol. 2020, 866, 172804-172816. [CrossRef] 
65. Nackiewicz, J.; Kliber-Jasik, M.; Skonieczna, M. A novel pro-apoptotic role of zinc octacarboxyphthalocyanine in melanoma me45 cancer cell's photodynamic therapy (PDT). J. Photochem. Photobiol. B Biol. 2019, 190, 146-153. [CrossRef] [PubMed]

66. Skonieczna, M.; Hudy, D.; Hejmo, T.; Buldak, R.J.; Adamiec, M.; Kukla, M. The adipokine vaspin reduces apoptosis in human hepatocellular carcinoma (Hep-3B) cells, associated with lower levels of $\mathrm{NO}$ and superoxide anion. BMC Pharmacol. Toxicol. 2019, 20, 58-66. [CrossRef] [PubMed] 